
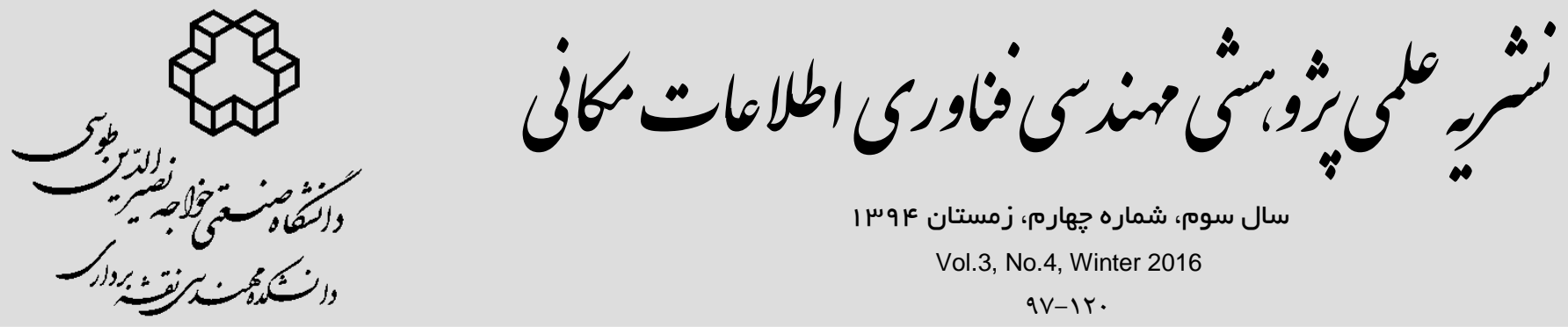

سال سوم، شماره جهارم)، زمستان ع وس

Vol.3, No.4, Winter 2016

$9 V-1 Y$.

\begin{abstract}
تعيين فاكتور هاى موثر بر آتشسوزى جنكَل با استفاده از تركيب ركرسيون

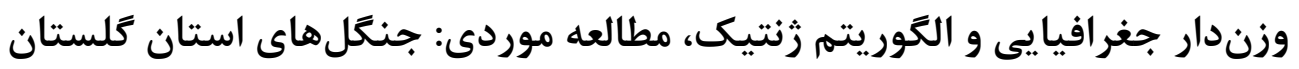

امين راعى'، يرهام بيهلوانى "مثمدى حسنلو'

ا - دانشجوى كارشناسى ارشد سيستمهاى اطلاعات مكانى، دانشكده مهندسى نقشهبردارى و اطلاعات مكانى، يرديس دانشكدههاى فنى دانشكاه تهران

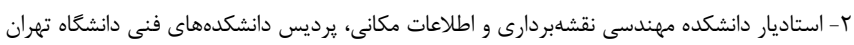

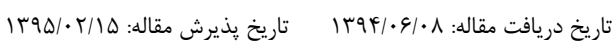

جكيده

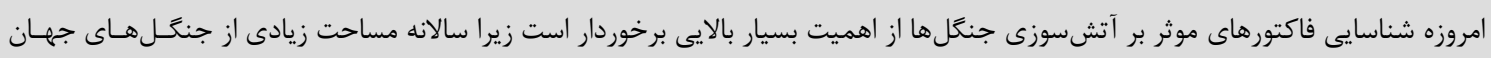

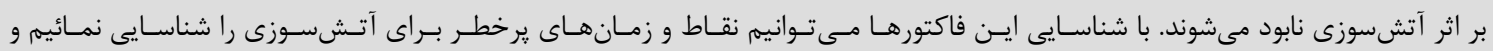

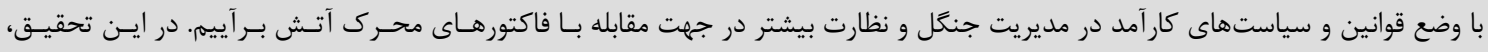

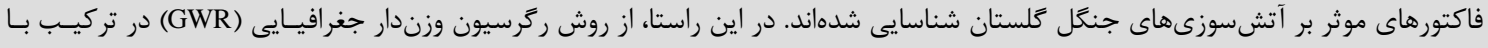

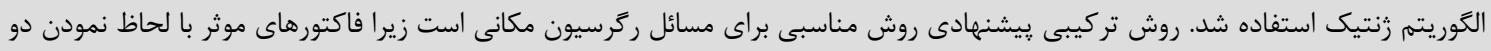

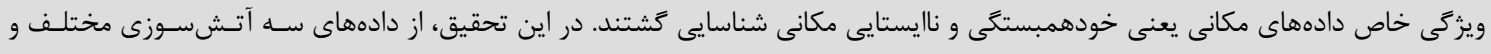

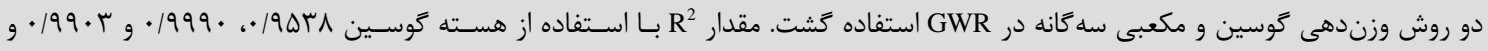

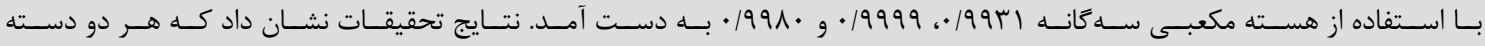

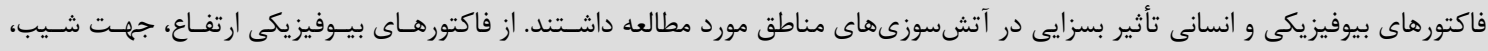

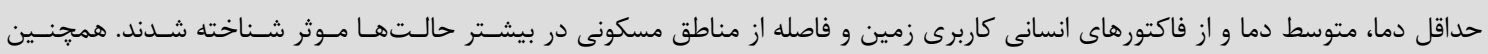

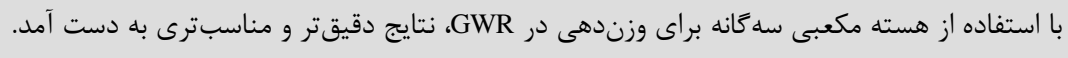

كليدوارهها: آتشسوزى جنكل، ركر سيون وزندار جغرافيايى، الكَوريته زنتيك، جنكل كلاستان. 


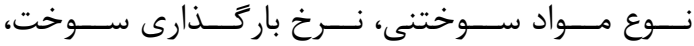

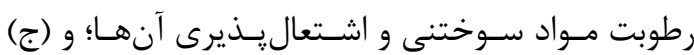
تويوكرافى منطقه مانند ارتفـاع، شـيب و جهـت شـيب.

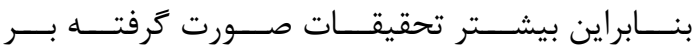

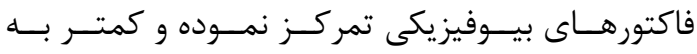

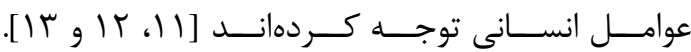

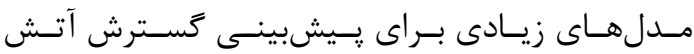

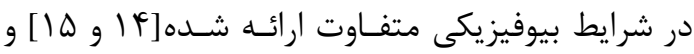

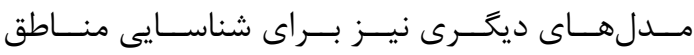

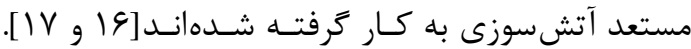

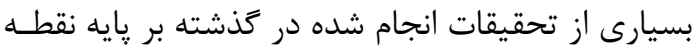

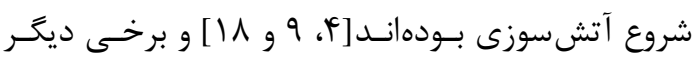

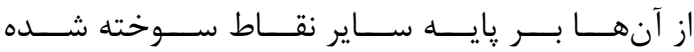

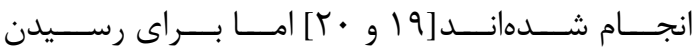

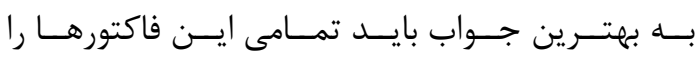

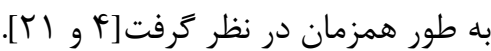
[Tr] عنوان نمود كه در مكزيك سـرعت حـداكثر بـاد،

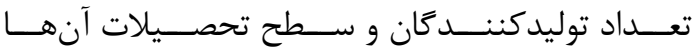
بيشترين تأثير را در آتشسوزى جنكَلها داشـته اسـت

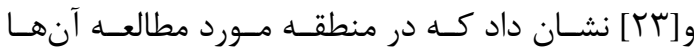

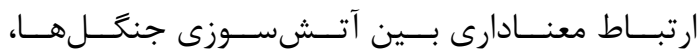
تــراكم جـادههـا و كـاربرى كشـاورزى وجـود دارد. [9.

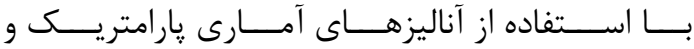

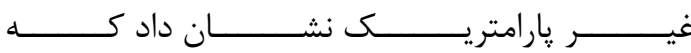

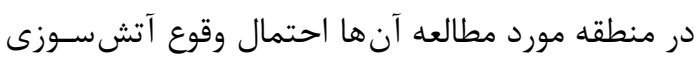
در محــلهـــاى قابـل دسترسـى توســ انســانهــا،

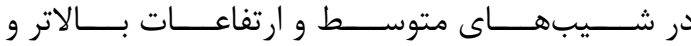

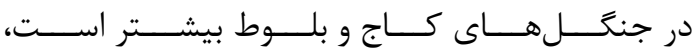

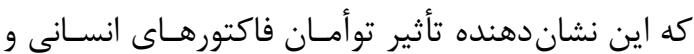

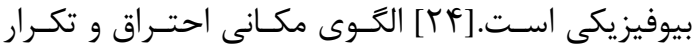

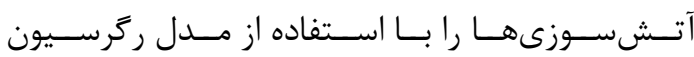

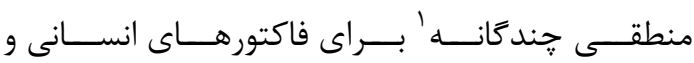

${ }^{1}$ Multiple logistic regression

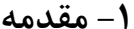

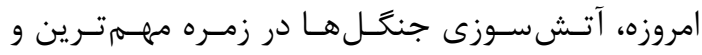

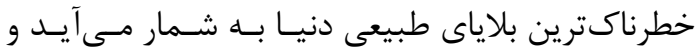

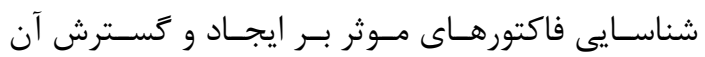
به منظور تشخيص سريع آتش و واكنش بدان ضـرورى

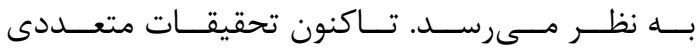
در اين زمينه صورت گرفته است. در بيشتر موارد انسان

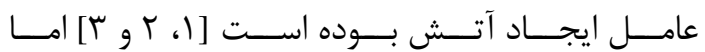

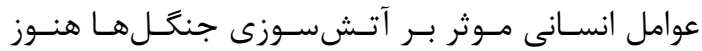
به درستى شناسايى نشده است.

دو دسته اصلى فاكتورهاى موثر بر آتشســوزى جنحـل كه در تحقيقات گذذشته مورد بحث قـرار زرفتـهـ شـامل

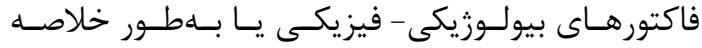

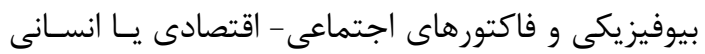

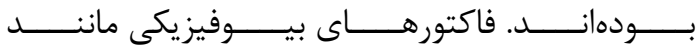
نـرخ باركـذارى ســوخت تنهــا فاكتورهـايى بودنـد كـهـ

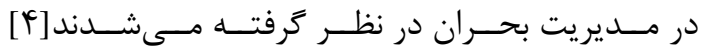

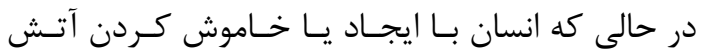

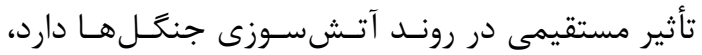

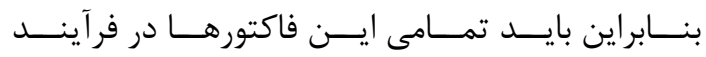

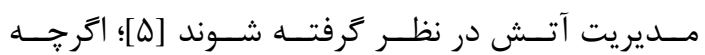

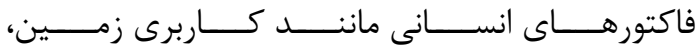
فرآيندهاى مديريت سـوخت، محسـدوديتهــاى قـانونى، ميزان دسترسى به جنگًل، عوامل فرهنگى، اجتمـاعى و

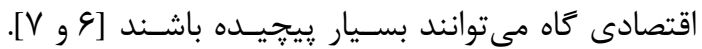
همجنــين مطـابق تحقيقــات انجــام شـده توســط [1]،

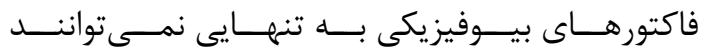

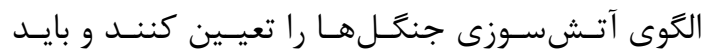

$$
\text { با ساير فاكتورها تركيب شوند. }
$$

اگرخه به طور كلى آتشسـوزى رفتـارى تصـادفى دارد

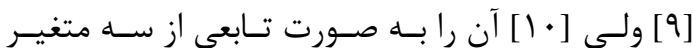
در نظر گرفت، شامل (الـف) شـرايط جـوى مانــد دمـا، رطوبـت، ميـزان بارنــدَى، جهــت عمــده وزش بــاد و

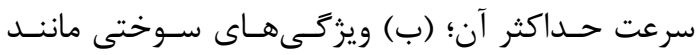


تأثير بيشترى هستند. تركيـبـهـاى متفـاوت فاكتورهـا

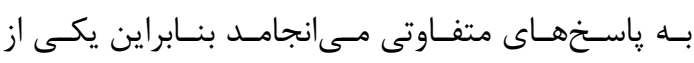
קالشهاى بيش رو يافتن تركيـب بهينـه فاكتورهاسـت كه بدين منظور از الكوريتم زنتيك استفاده نموديم. در ادامه تحقيق حاضر، در بخش r بــهـ معرفى منطقـهـ مورد مطالعه، دادهاى مورد اسـتفاده، روش ركرسـيون دئن

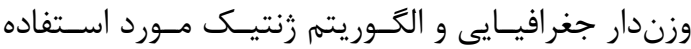

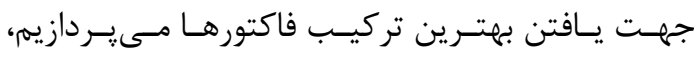
در بخش ץ نتايج به دست آمده ارائسه و وِيرامـون آنهـا بحث شده است و در نهايت، در بخش لأ به نتيجه كيرى از اين تحقيق مىيردازيم.

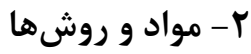

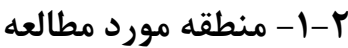

جنكل كلستان از مهمترين مناطق جنكلى ايـران واقع در شرق استان كلستان و غرب استان خراسـان شـمالى إنى

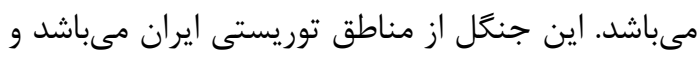
جادهاى ارتباطى متعددى از ميان آن عبـور مسى كنــد.

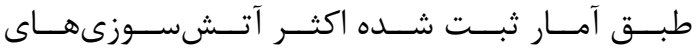

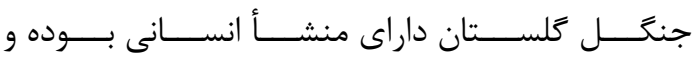
در مجاورت اين جادهها رخ دادهاند. منطقه مورد مطالعه اين تحقيق (شكل l)، در محسدوده 'TV

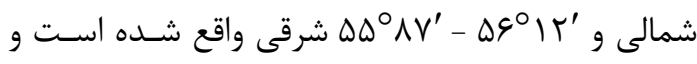

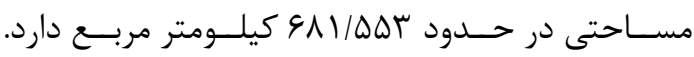
بخش عمده منطقه مورد مطالعه اين تحقيق در اسـتان

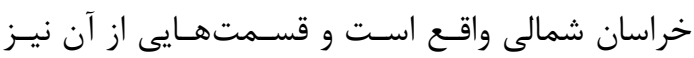

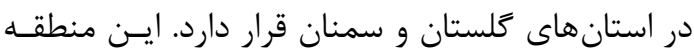
به كونهاى انتخاب شده است كه به لحاظ اقليمى داراى خصوصيات يكسانى باشد. شكل r منطقه مورد مطالعـه

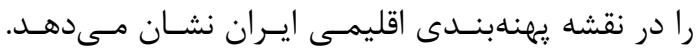

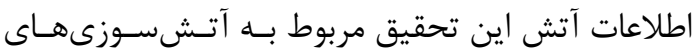

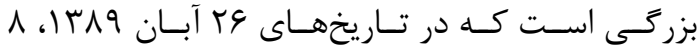

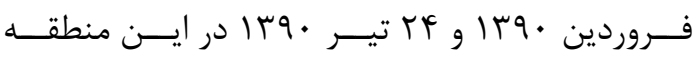

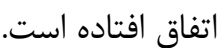

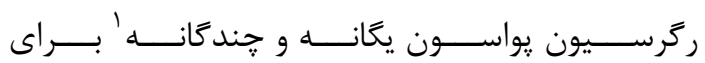

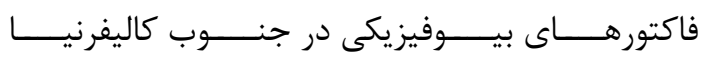
مدل سازى كرد و نتيجه كرفت كه ميزان احتراق بيشـتر

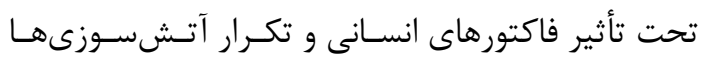

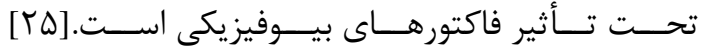

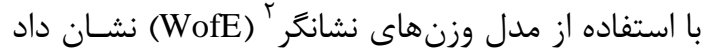

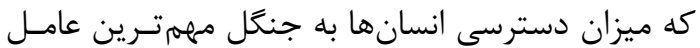

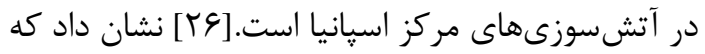

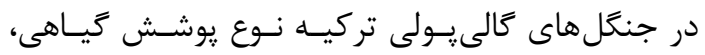

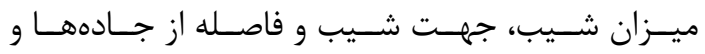

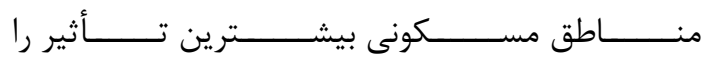
در آتشسوزى جنگل ها دارد.

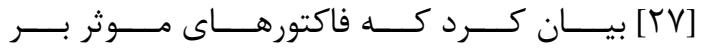

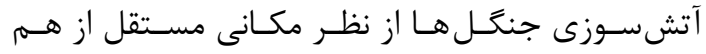

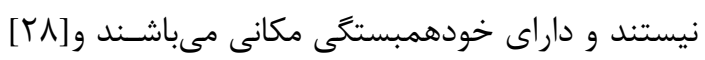

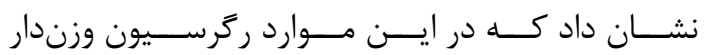

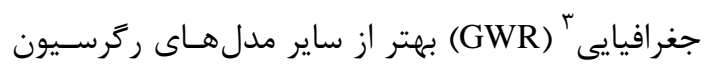

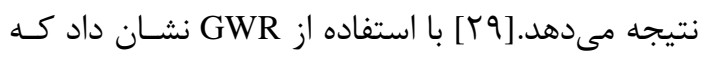

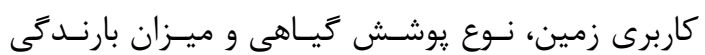

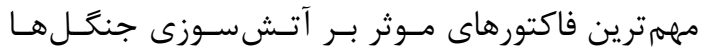

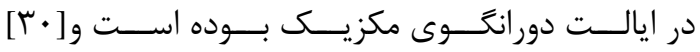
با استفاده از اين مــل در منطقــه مـورد مطالعـهـ خــود

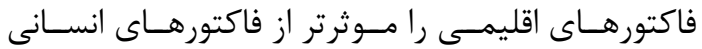
تشخيص داد.

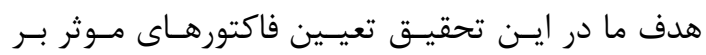
آتشسوزى هاى بخشى از جنكل كلستان بـا اسـتفاده از

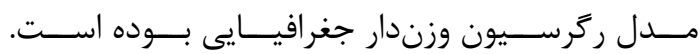

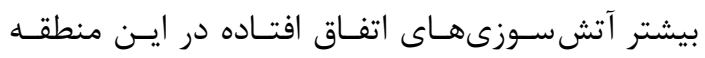

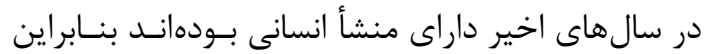
هر دو فاكتور بيوفيزيكى و انسانى را در نظـر كـرفتيمه و

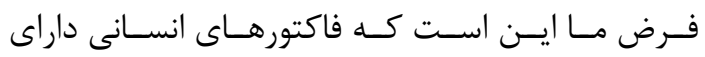

${ }^{1}$ Poisson univariate and multiple regressions

${ }^{2}$ Weights of Evidence

${ }^{3}$ Geographically Weighted Regression 


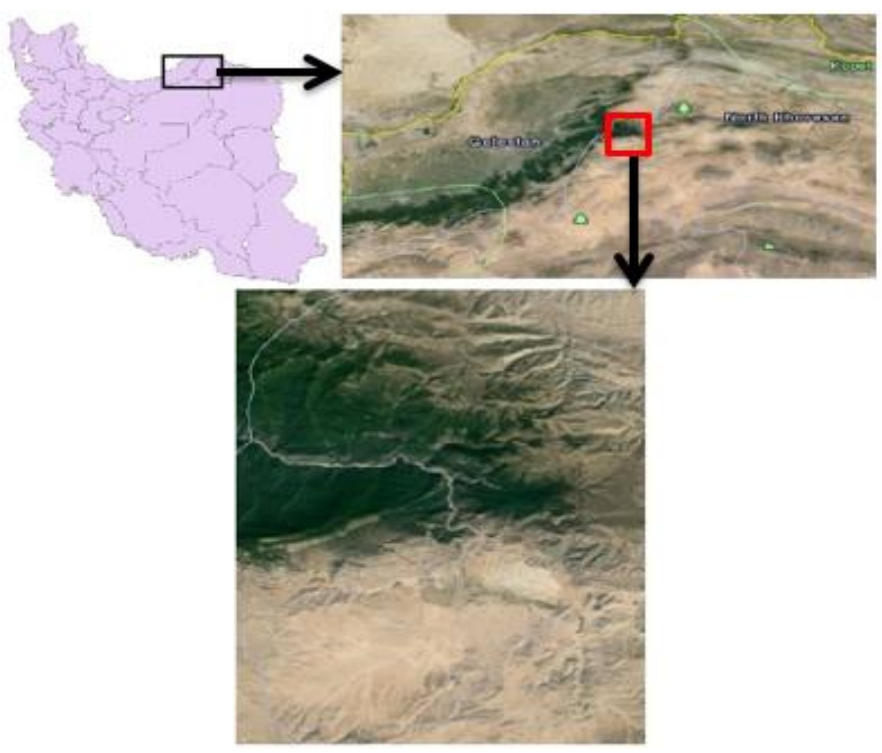

شكل ا: منطقه مورد مطالعه

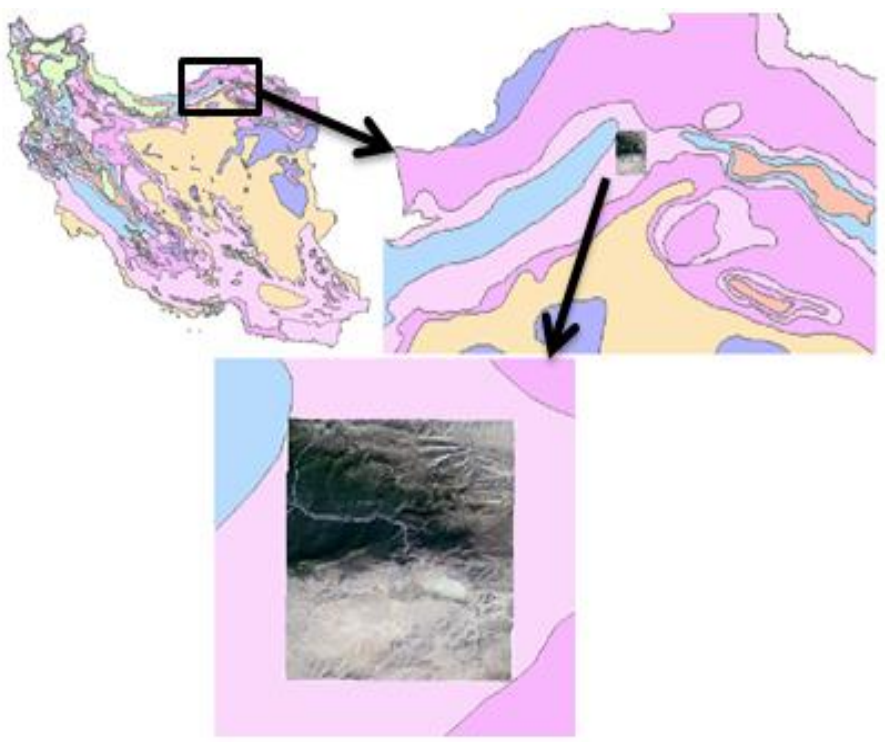

شكل r: منطقه مورد مطالعه در نقشه يهنهـبندى اقليمى ايران

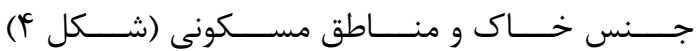
r

از سازمان نقشهبردارى كشور و اداره كل منابع طبيعى

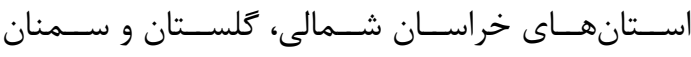

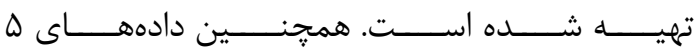

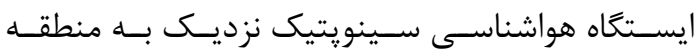
مورد مطالعه (شكل ف) به همراه مختصات مكانى آنهـا از طريق سازمان هواشناسى كشور به دست آمده است.
بخشـى از دادههــاى مــورد نيــاز ايسـن تحقيـق شـامل

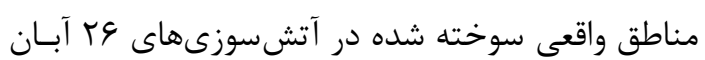

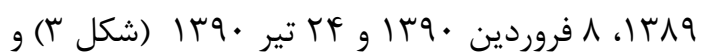
دادههاى ديخرى از قبيل مدل رقومى ارتفاعى' (DEM)

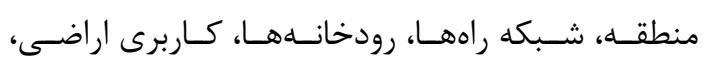

${ }^{1}$ Digital Elevation Model 

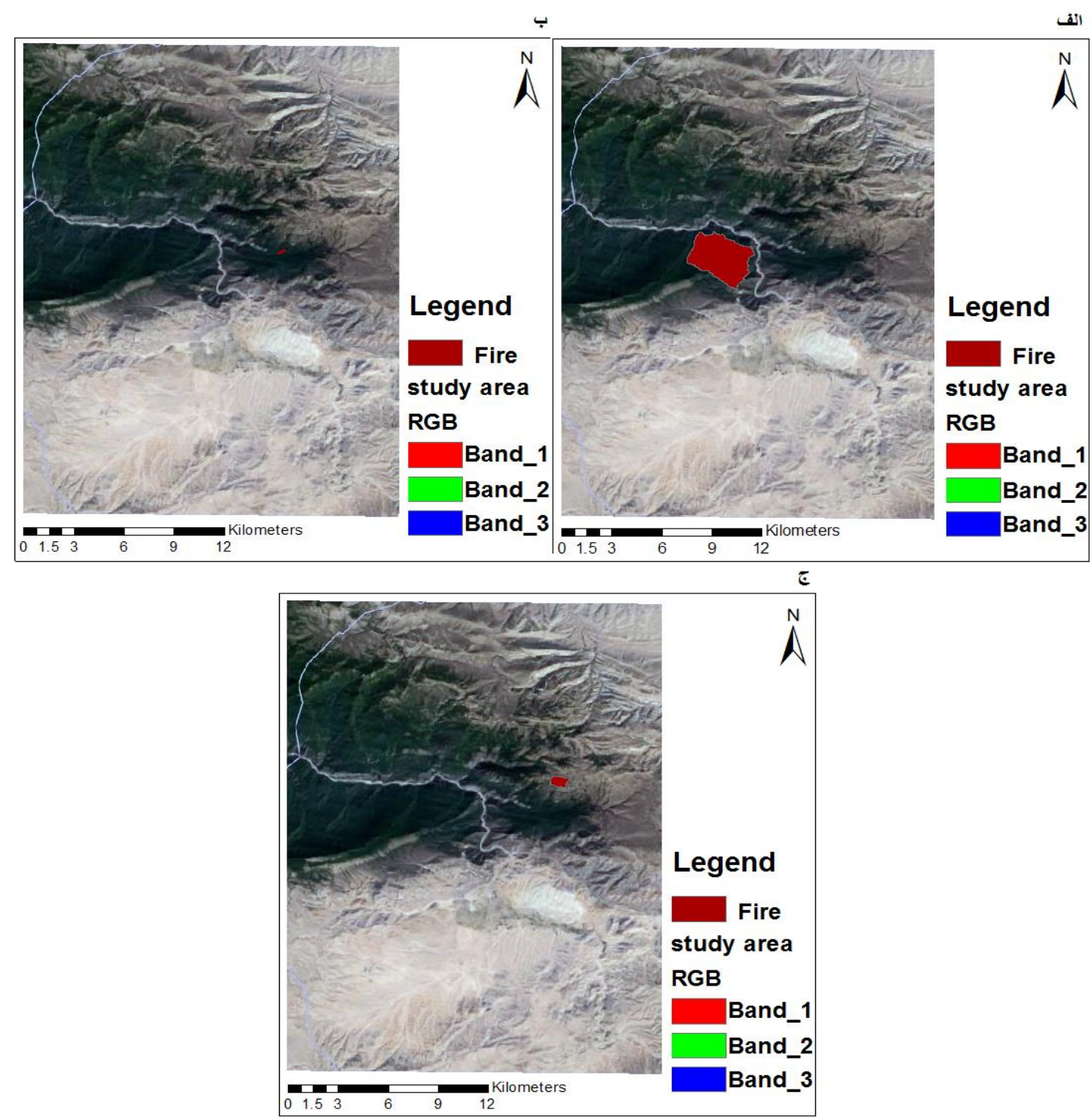

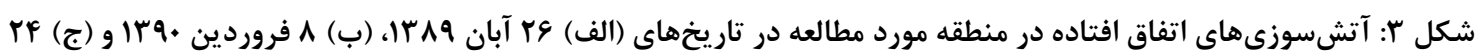

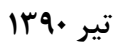

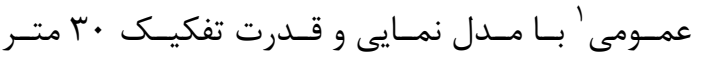

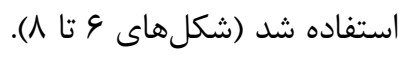

ايـن دادهـــا شـامل حـــاكثر، حـــاقل و متوسـط دمــا،

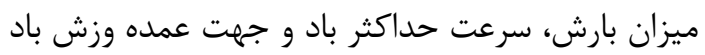

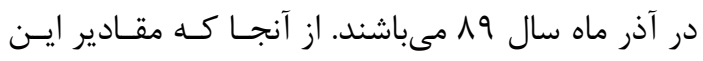

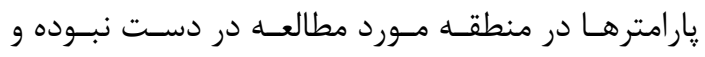

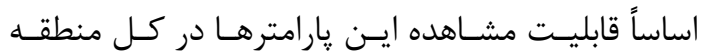

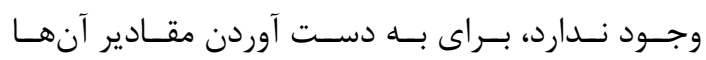

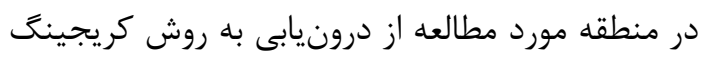

\footnotetext{
${ }^{1}$ Ordinary Kriging
} 

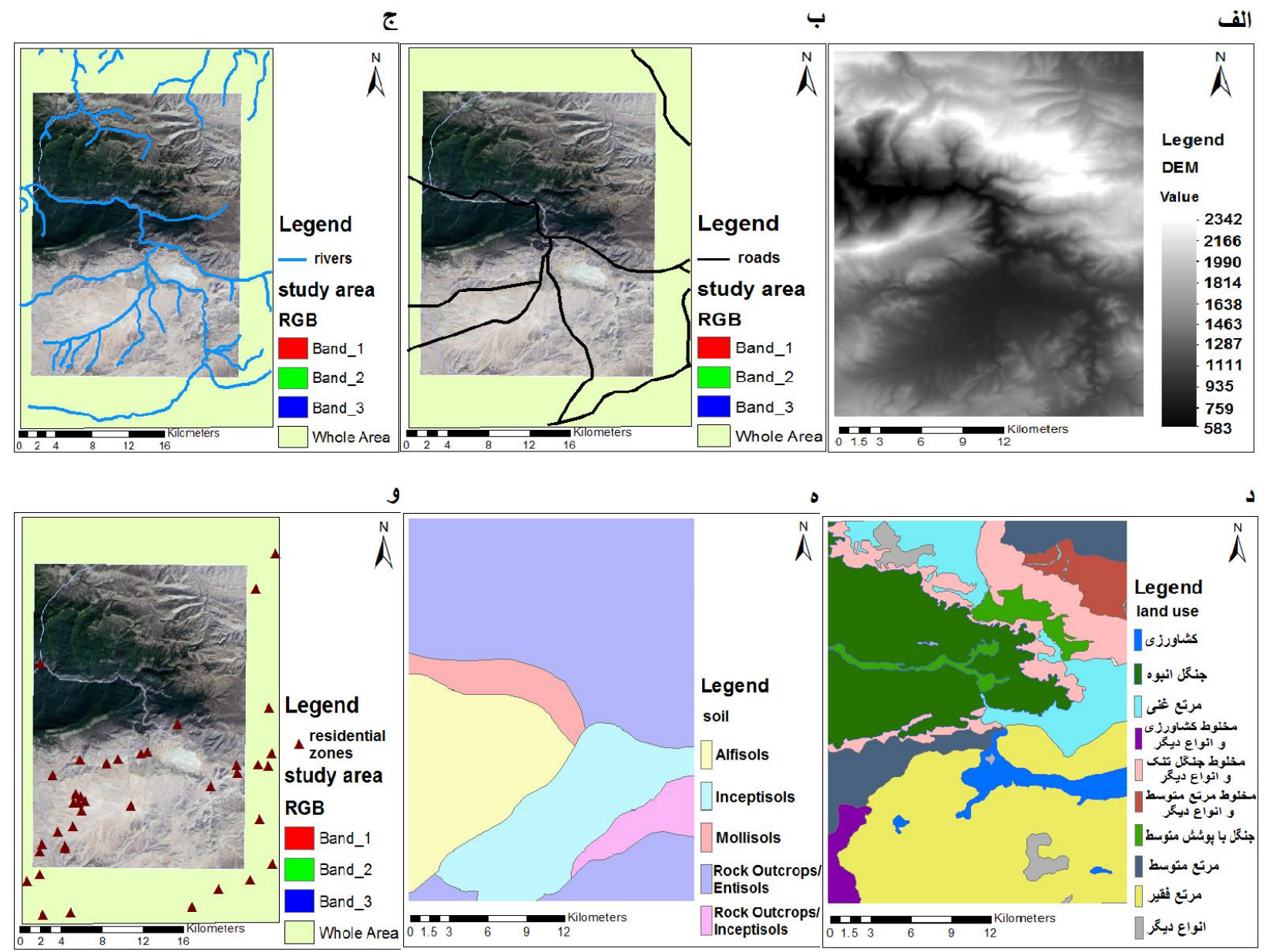

شكل f: لايههاى اطلاعاتى مورد استفاده در اين تحقيق (الف) مدل رقومى ارتفاعى منطقه، (ب) شبكه راهها، (ج) رودخانهها، (د)

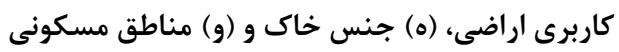

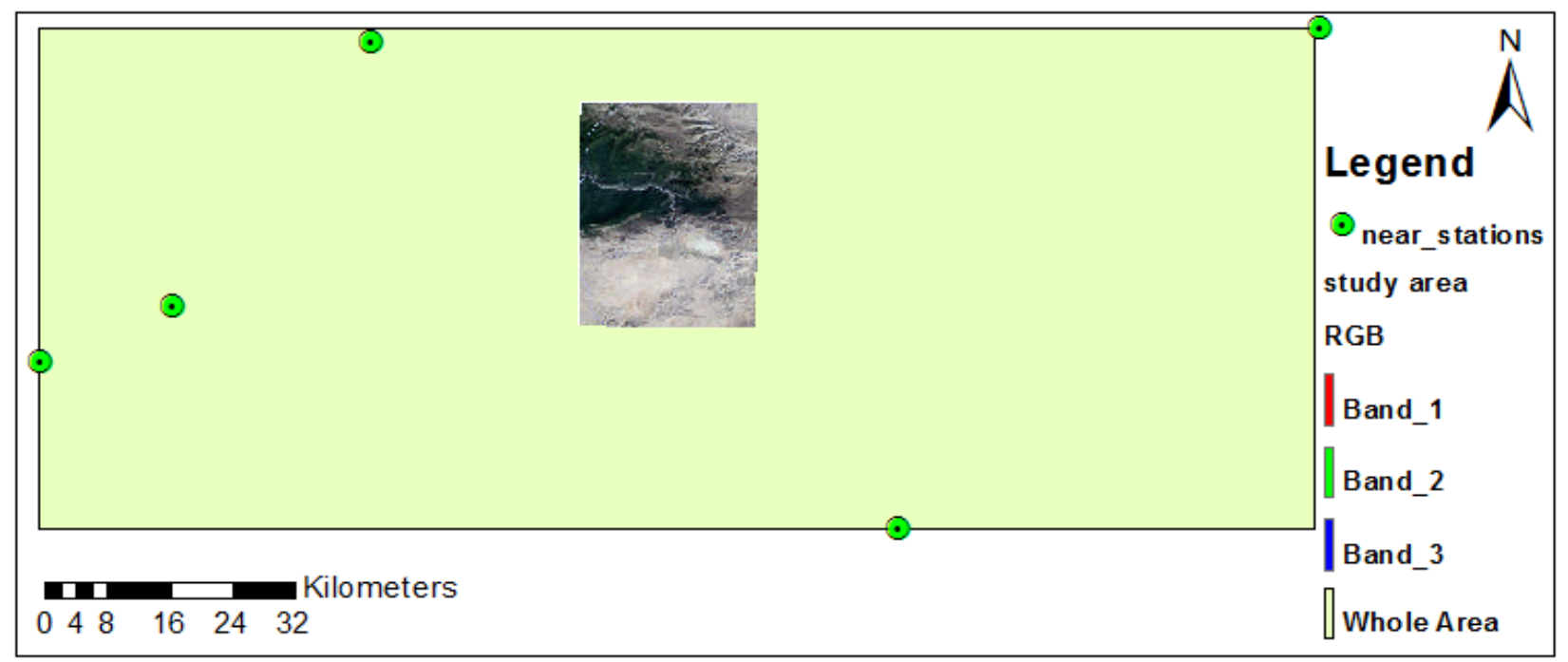

شكل ه: ايستگًاهاى هواشناسى سينويتيك نزديك به منطقه مورد مطالعه 

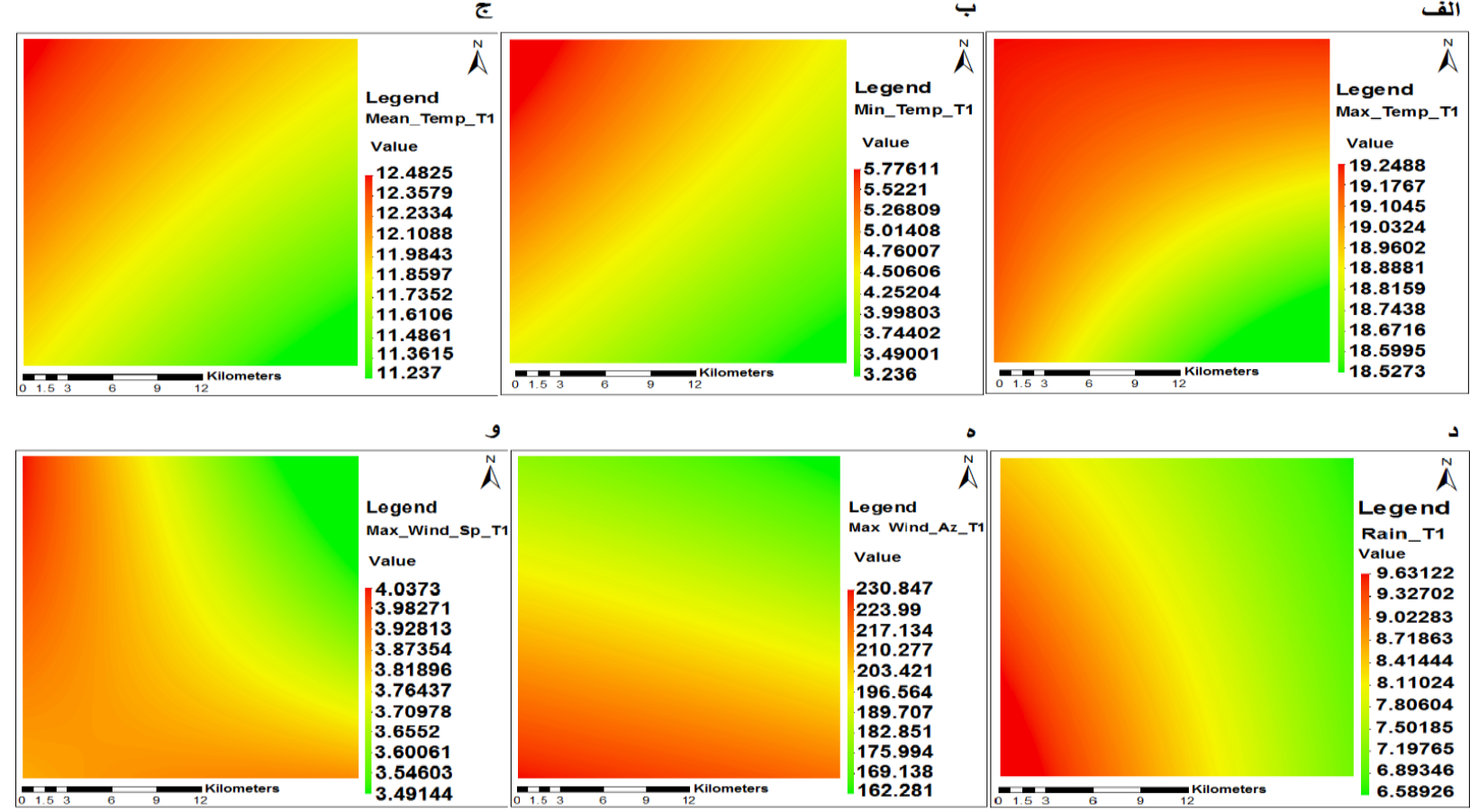

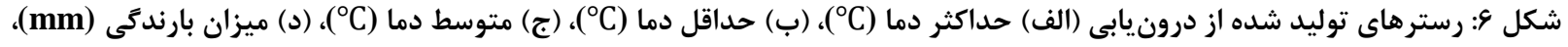

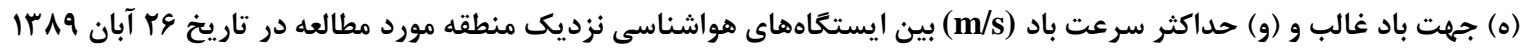

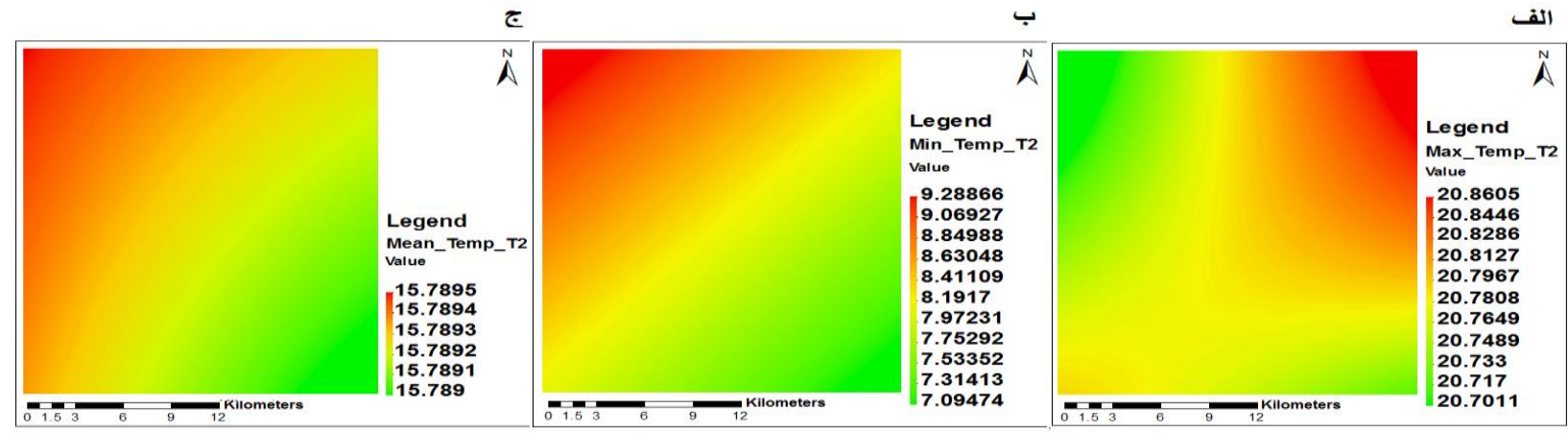

(d)
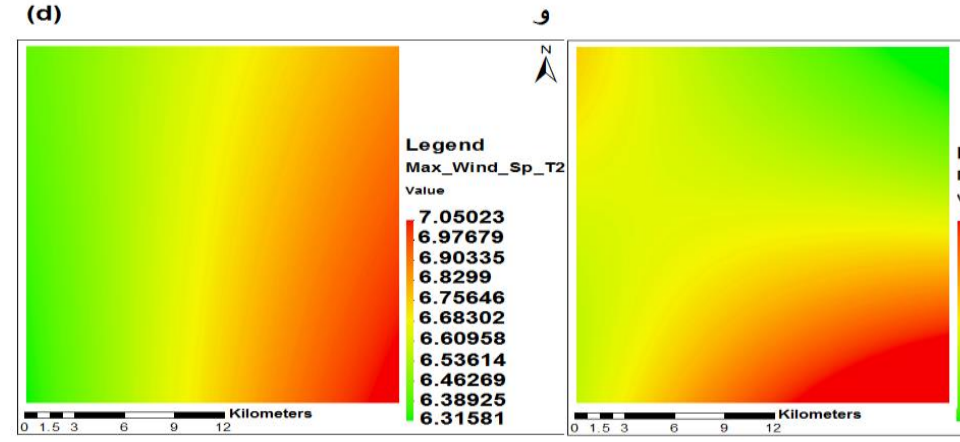

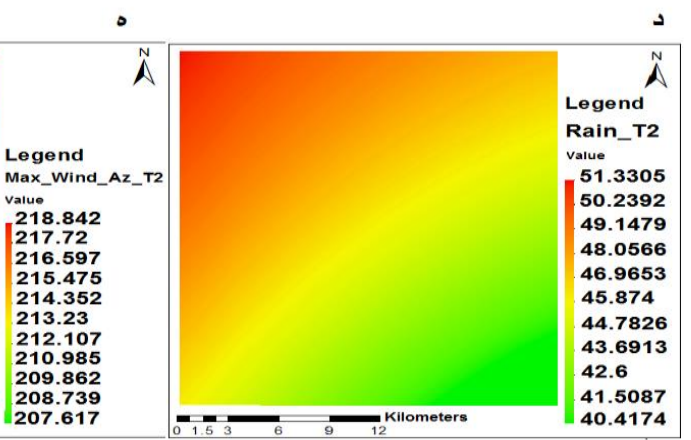

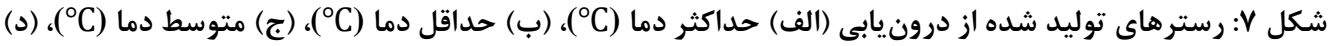

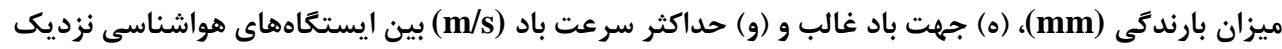

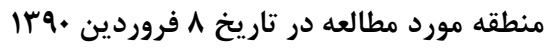



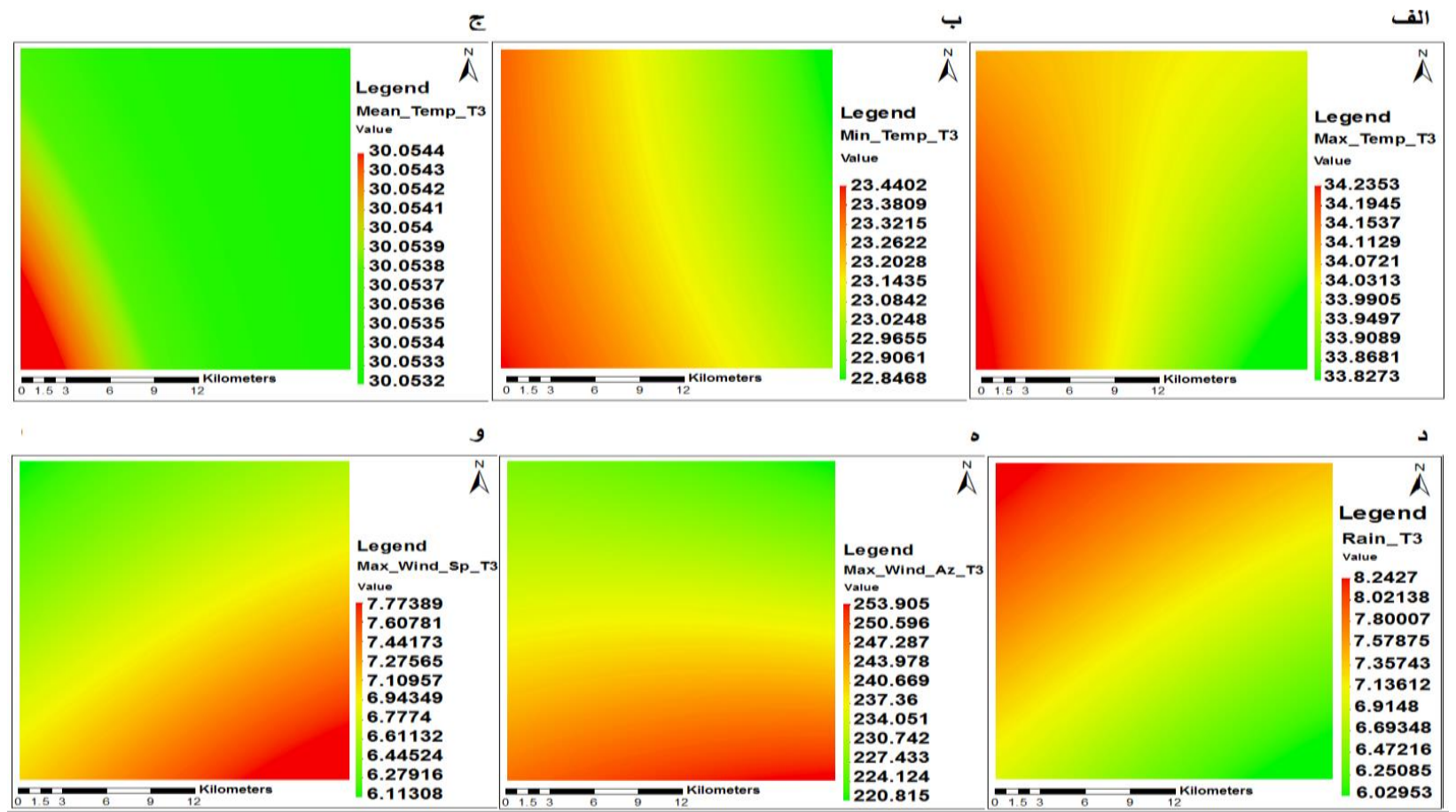

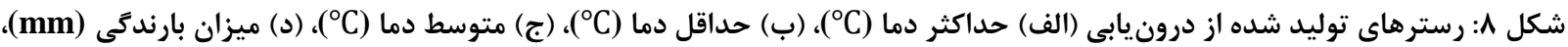

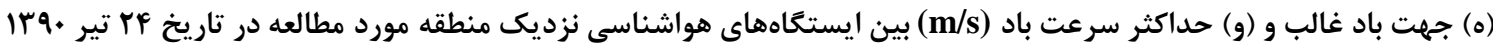

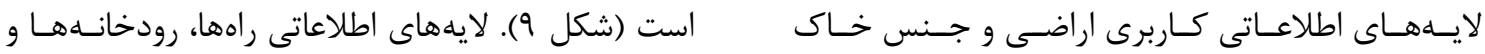

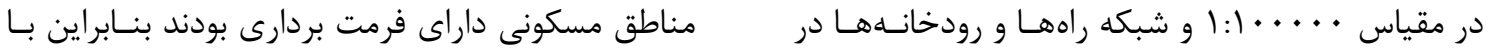

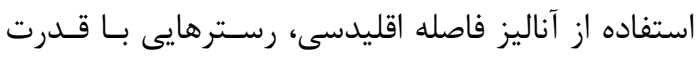

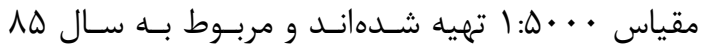
تفكيك هـ متر توليد گشت كه هر سلول آن نشاندهنده آسابه مىباشند. مدل رقومى ارتفاعى منطقه از سازمان نقشـهـ

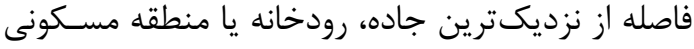

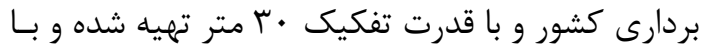

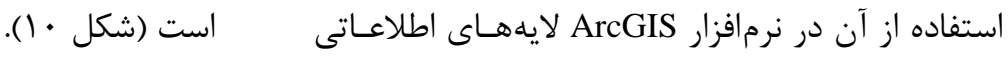

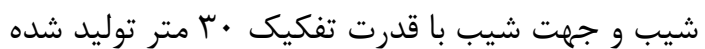

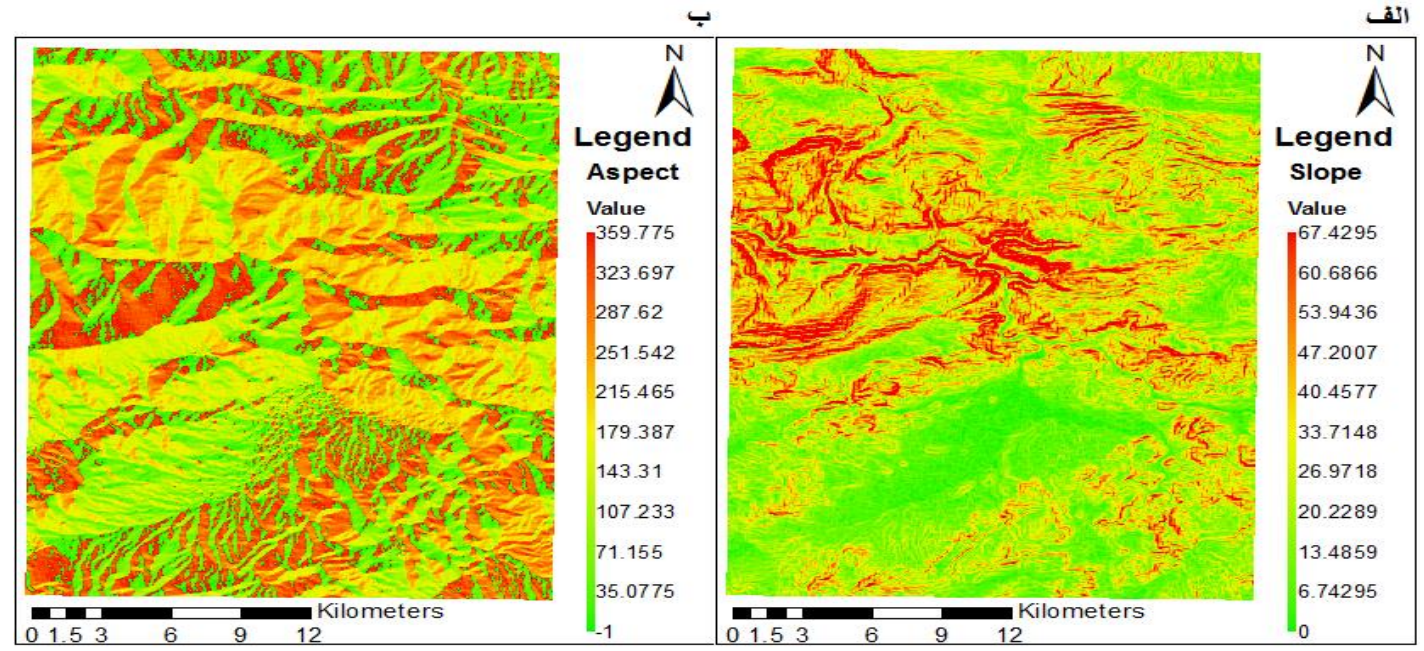

شكل 9: لايههاى اطلاعاتى (الف) شيب و (ب) جهت شيب 


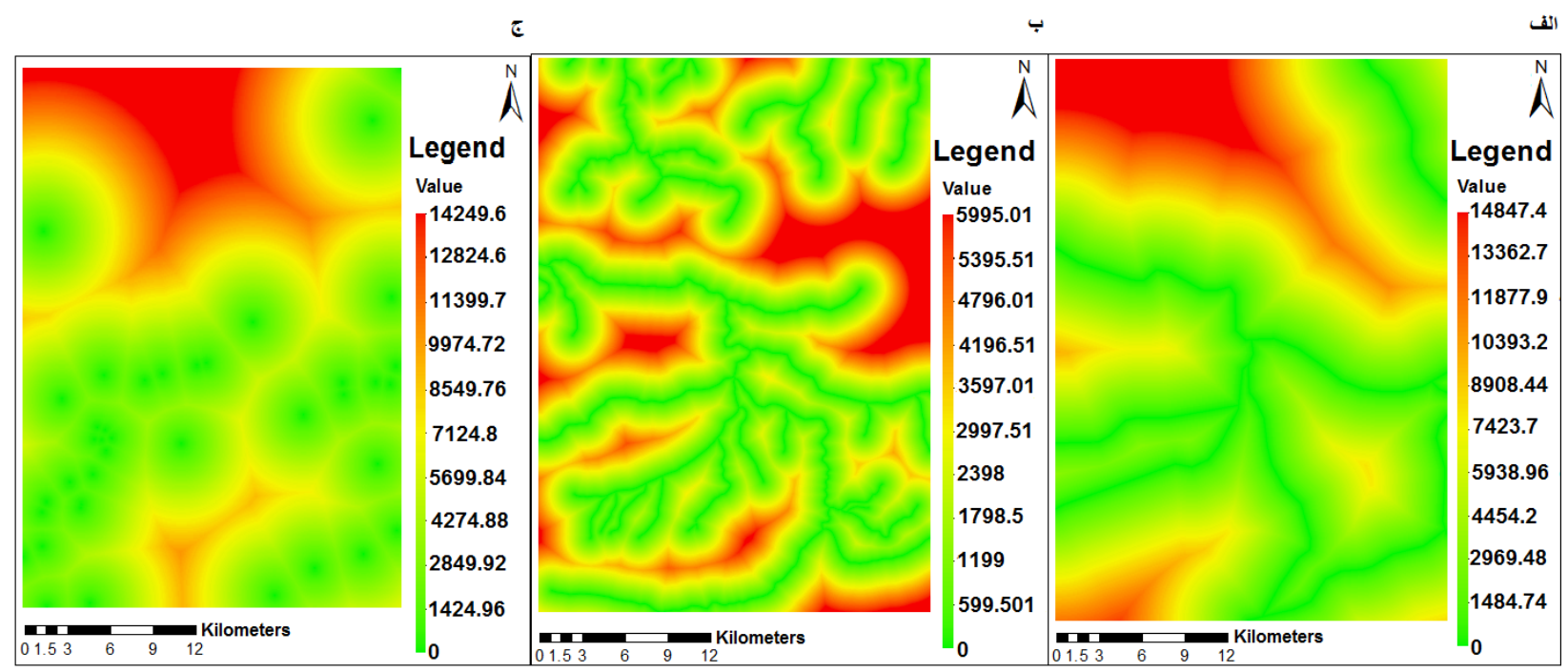

شكل •ا: لايههاى اطلاعاتى فاصله از (الف) جادهها (m)، (ب) رودخانهها (m) و (ج) مناطق مسكونى (m)

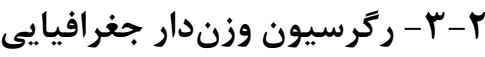

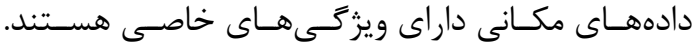

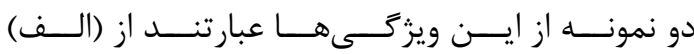
خودهمبستكى مكانى 'بر اساس قانون تـابلر كـه بيـانكر

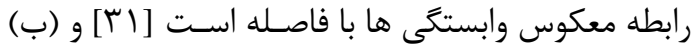

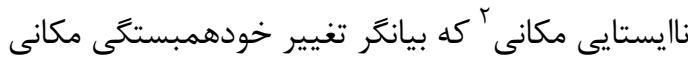

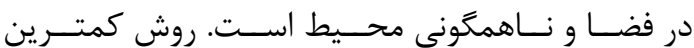

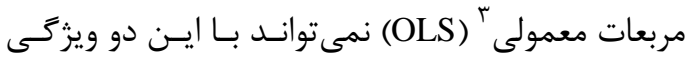

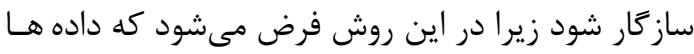

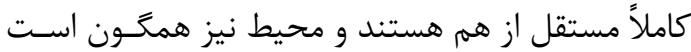

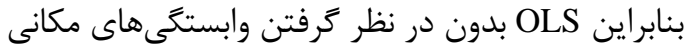
براى تمامى نقاط منطقه يك دسته جواب ارائه مى دهد.

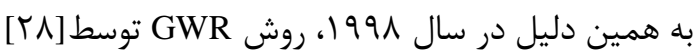

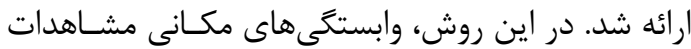
به صورت ماتريس هاى وزن در نظــر خرفتـه مسى شــود و

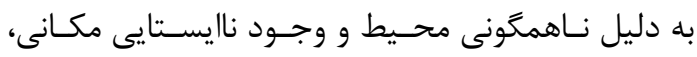

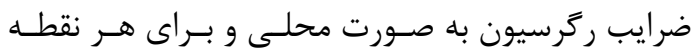
به طور جداكانه به دسـت مسى آيـد. رابطـهـ كلـى GWR بدين صورت است:

\footnotetext{
${ }^{7}$ Spatial autocorrelation

${ }^{8}$ Spatial non-stationarity

${ }^{9}$ Ordinary Least Squares
}

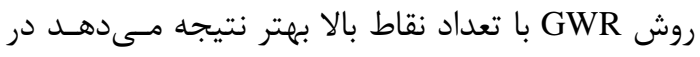

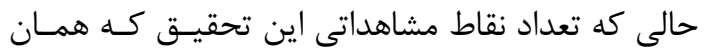

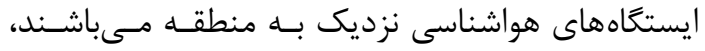

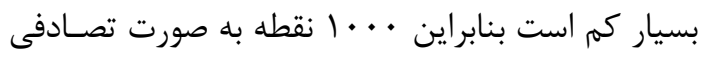
البته با تراكم بيشتر در محدوده آتش در منطقـهـ مـورد

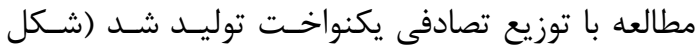

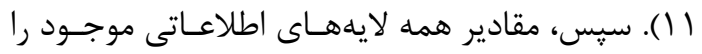

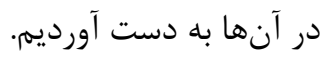

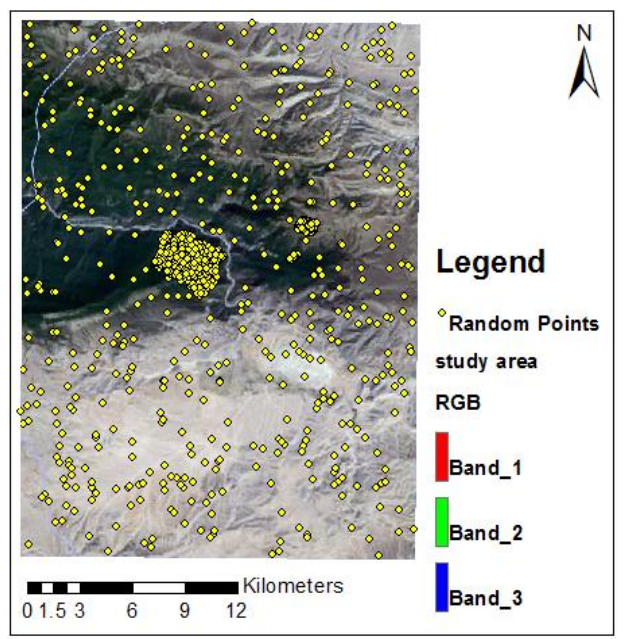

شكل ||: نقاط تصادفى توليد شده در منطقه مورد مطالعه 


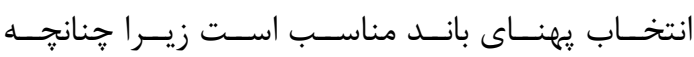

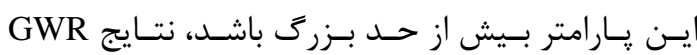

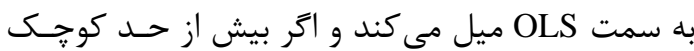

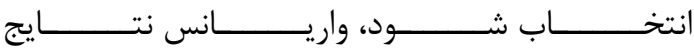

به شدت افزايش مى يابد[بّ].

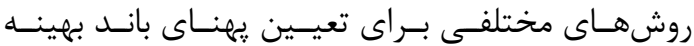

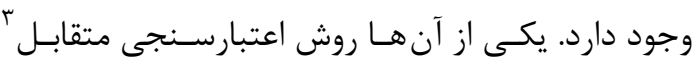

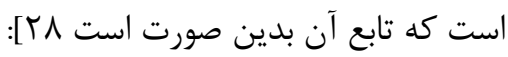

$$
\text { رابطه (申) ( }
$$

كـهـ

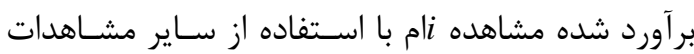

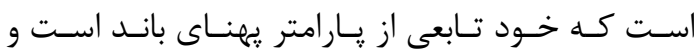
هر بهناى باندى كه اين تابع را مينيمم كند بــهـ عنـوان بهناى باند بهينه در نظر ترفته مىشود. خروجى GWR شامل پِارامترهـاى متعـددى اسـت كـهـ

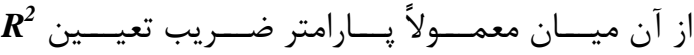
براى سنجش خوبى برازش مدل بـهـ كـار مس رود [بسّ].

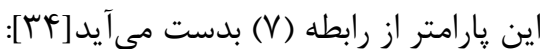

$$
R^{2}=1-\frac{S S_{E}}{S S_{T}}
$$

(V) رابطه

$S S_{E}=\sum_{i=1}^{n}\left(y_{i}-\hat{y}_{i}\right)^{2}$

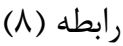

$$
S S_{T}=\sum_{i=1}^{n}\left(y_{i}-\bar{y}\right)^{2}
$$

كــهـ n تعـــاد مشــاهدات، برآورد شده مشاهده iام و

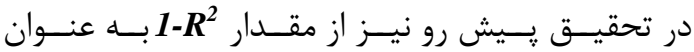

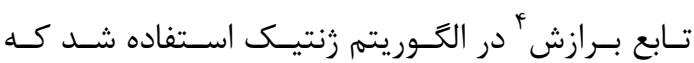

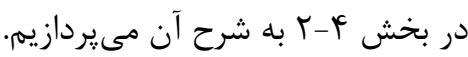

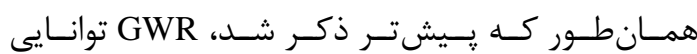
مدل سازى تغييرات محلـى و نايسـتايى مكـانى را دارد.

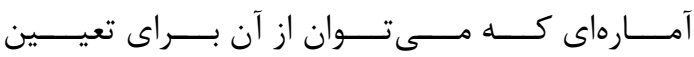

\footnotetext{
${ }^{12}$ Cross Validation
}

${ }^{13}$ Fitness function $y=\beta_{0}(u, v)+\sum_{j=1}^{p} \beta_{j}(u, v) X_{j}+\varepsilon \quad(1)$

كــه در آن y متغيــر وابسـته، X

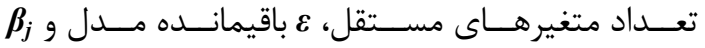

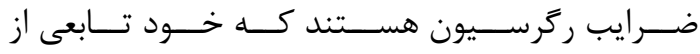

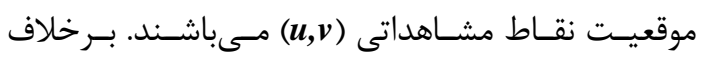
GWR ، OLS ضرايب ركرسيون را از طريق رابطه زير بدست مى آورد: رابطه (T) $\hat{\beta}(u, v)=\left(X^{T} W(u, v) X\right)^{-1} X^{T} W(u, v) y$ كه در آن W Wـاتريس وزن مشـاهدات اسـت كـه خـود

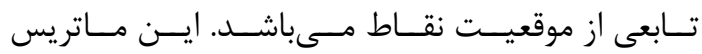

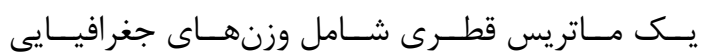
به شكل رابطه (ז) است: $\left[\begin{array}{ccc}W_{1}(u, v) & 0 & 0 \\ 0 & \ddots & 0 \\ 0 & 0 & W_{n}(u, v)\end{array}\right] \quad$ (r) تعيين وزن هاى جغرافيايى در GWR از اهميـت بـالايى

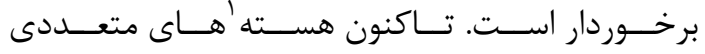

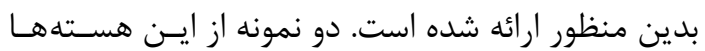

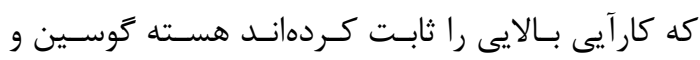

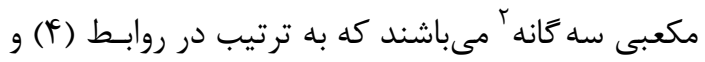

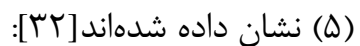

$$
\begin{aligned}
& W_{i j}=\varphi\left(\frac{d_{i j}}{\sigma h}\right) \\
& \text { رابطه (F) } \\
& W_{i j}=\left\{\begin{array}{cl}
\left(1-\left(\frac{d_{i j}}{h}\right)^{3}\right)^{3} & , d_{i j} \leq h \\
0 & , d_{i j}>h
\end{array} \quad\right. \text { (ه) }
\end{aligned}
$$

كه $W_{i j}$ وزن جغرافيايى مربوط به مشاهده زام در نقطـهـ iام،

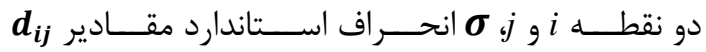

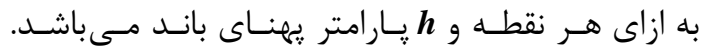

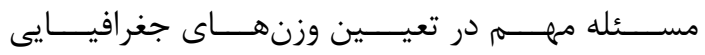

\footnotetext{
${ }^{10}$ Kernel

${ }^{11}$ Tricube
} 
تقريباً تصادفى باشند و مقدار اين آماره نزديك به صـفر

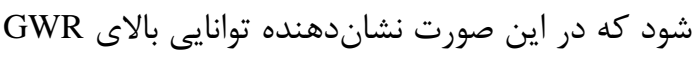
در مـــلســازى خودهمبســتخى مكــانى مشــاهدات

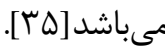

\section{Y-F- انتخاب فاكتور هاى بهينه}

در ايـن مرحلـه، نسـبت بــه انتخــاب زيرمجموعـهاى از

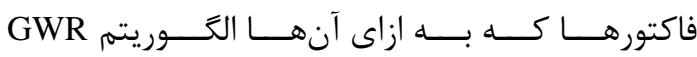

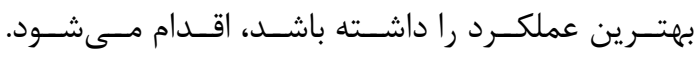

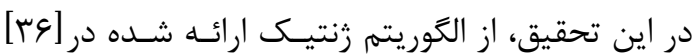

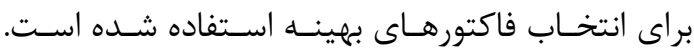

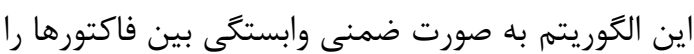

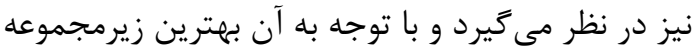

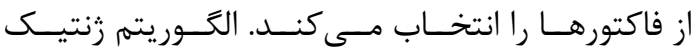

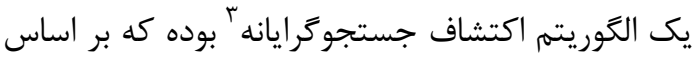
انتخاب طبيعى كار مى كند. ايسن اكتشـاف اغلـب بـراى حل مسائل جستجو و بهينهسازى به كار برده مىشـود.

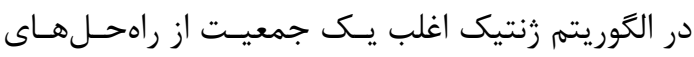

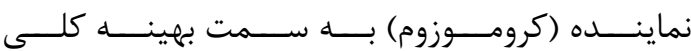

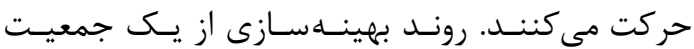

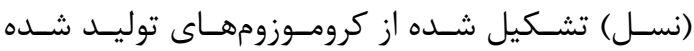
به صورت اتفاقى شروع مىشود. در هر نسل تابع برازش براى تمامى كروموزومهاى آن نسل محاسـبه مسىشـود.

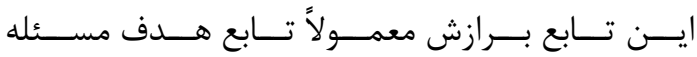

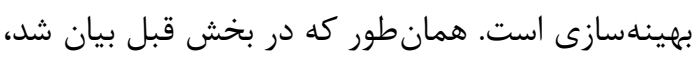
تابع برازش الكوريتم زنتيك ييشنهادى اين تحقيـق، - 1

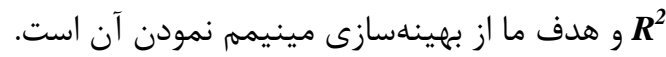

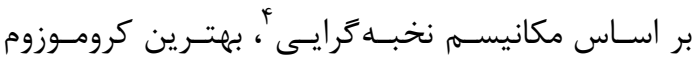

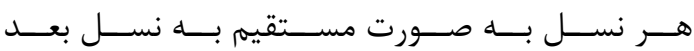
منتقل مى كردد. همجنِين، كروموزومهــاى داراى مقــدار

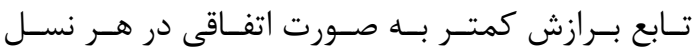

\footnotetext{
${ }^{15}$ Search Heuristic
}

${ }^{16}$ Elitism

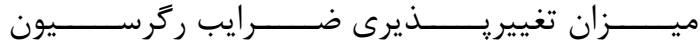
در منطقه مورد مطالعه استفاده نمود، انحراف استاندارد

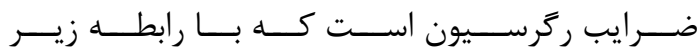

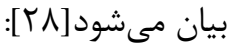

$$
v_{j}=\sqrt{\sum_{i}\left(\beta_{i j}-\beta_{. j}\right)^{2} / n} \quad \text { (l) }
$$

كه

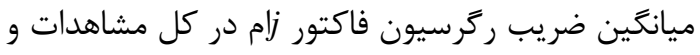
n n تعداد مشاهدات مىباشد. همجنـــن مقــادير خطـاى جـــر ميـانكين مربعـات'

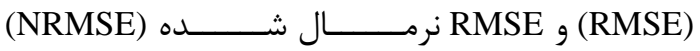

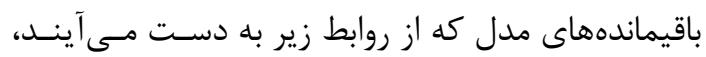
به منظور سنجش توزيع اين باقيماندهها به كار مىروند:

$$
\begin{array}{ll}
\boldsymbol{R M S E}=\sqrt{\frac{1}{n} \sum_{i=1}^{n}(y-\hat{y})^{2}} & \text { (1) رابطه } 1 \text { رابطه (I) } 1 \text { (I) }
\end{array}
$$

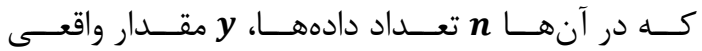

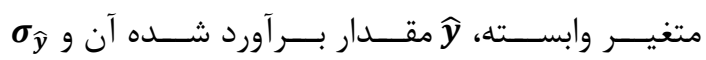
انحراف معيار مقادير برآورد شده متغير وابسته است.

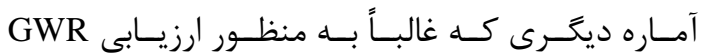

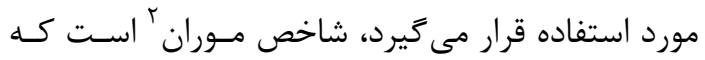
رابطه آن به صورت زير مىباشد [بَّ]: $I=\frac{n \sum_{i=1}^{n} \sum_{j=1}^{n} w_{i, j} z_{i} z_{j}}{S_{0} \sum_{i=1}^{n} z_{i}^{2}}$

رابطه (I) كه n تعداد مشـاهدات، $j$ و

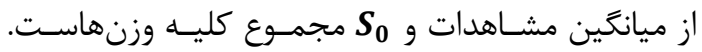

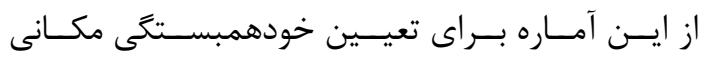

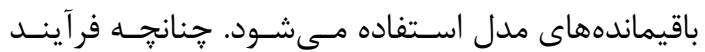
سرشكنى خطاها بـه درسـتى انجـام شـود مسى بايسـت

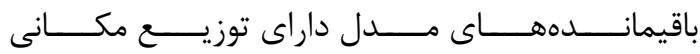

\footnotetext{
${ }^{1}$ Root Mean Squares Error

${ }^{15}$ Moran's I
} 
در نظر كرفته شـدهانـد. ايسن عا عـاكتور بـا توجـهـ بـهـ

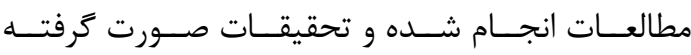
در كذشــته و محسـدوديتهــاى موجــود در دسترسـى مـ

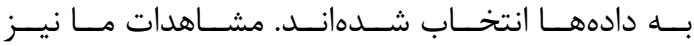
به صورت دودويى ( البراى آتش و • بــراى غيـر آتـش)

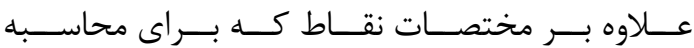

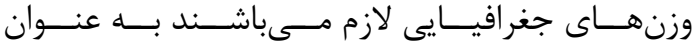

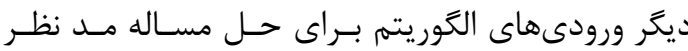

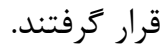

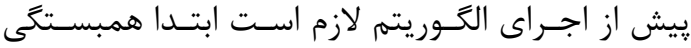

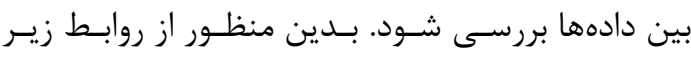
استفاده مىشود [rV]

$$
\begin{aligned}
& \operatorname{Cov}(X, Y)=\frac{\sum_{i=1}^{n}\left(X_{i}-\bar{X}\right)\left(Y_{i}-\bar{Y}\right)}{n} \quad \text { (I Y Y ) } \\
& r=\frac{\operatorname{Cov}(X, Y)}{\sigma_{X} \sigma_{Y}}
\end{aligned}
$$

كه در آنها و

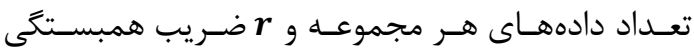
بــين دو مجموعـه داده بـا انحــراف معيارهـاى

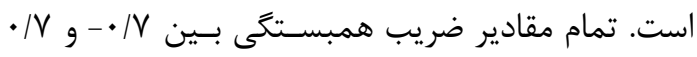

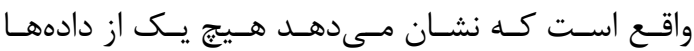

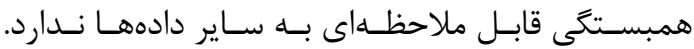

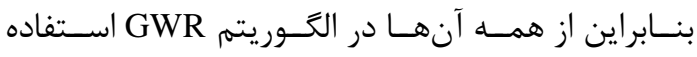

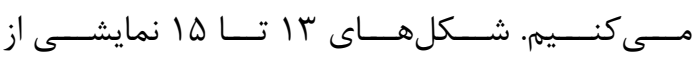
ماتريس همبستگى بين مجموعه دادههاى مورد استفاده در اين مطالعه با ترتيبى مطابق جدول 1 مىباشد.
بـر اسـاس مكانيسـم انتخــاب؛ انتخــاب شـده و زنــوم

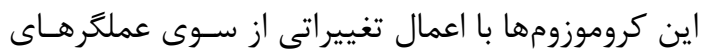

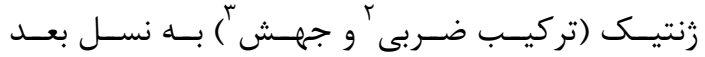

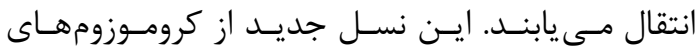

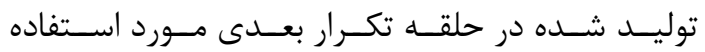

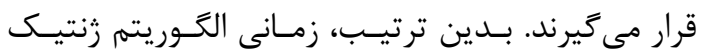

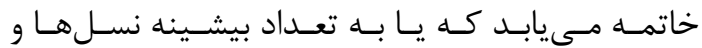
يا به مقدار تابع بــرازش رضـايت بخـش رســيده باشــد.

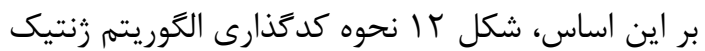
ييشــنهادى ايـن تحقيـق بــراى حــل مســــله يــافتن

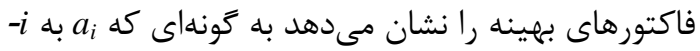
امين فاكتور اشاره دارد.

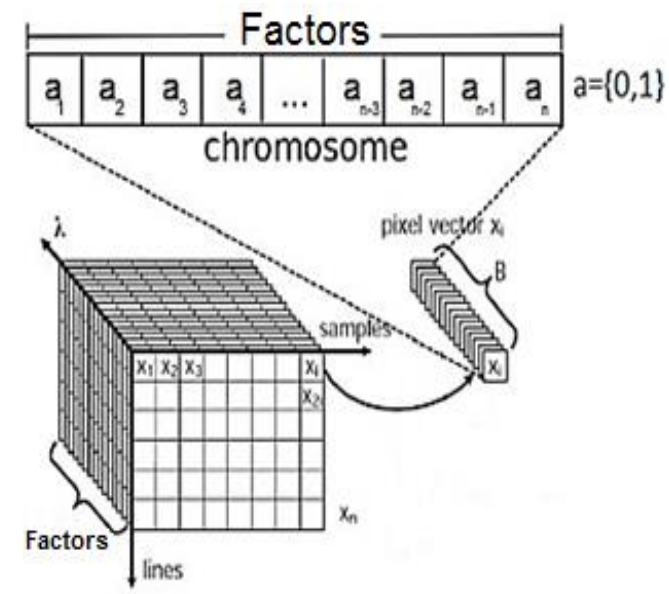

شكل rا: نحوه كدكذارى هر كروموزم الكَوريتم زنتيك ريشنهادى اين تحقيق براى حل مسئله يافتن فاكتورهاى بهينه

$$
\text { r- ييادهسازى و ارزيابى }
$$

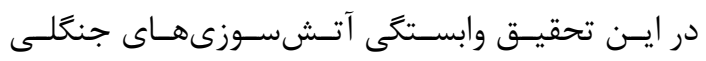

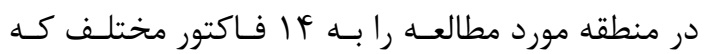

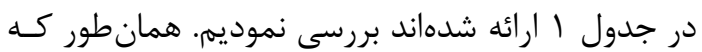

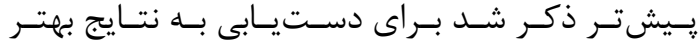

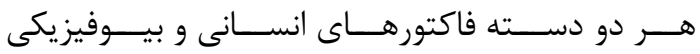

\footnotetext{
${ }^{17}$ Genome

${ }^{2}$ Crossover

${ }^{3}$ Mutation
} 
جدول 1: فاكتورهاى مورد مطالعه در اين تحقيق

\begin{tabular}{|c|c|c|c|c|c|}
\hline فاكتور & شماره & فاكتور & شماره & فاكتور & شماره \\
\hline متوسط دما (Co ) & 11 & ارتفاع (m) & 4 & فاصله از رودخانهها (m) & 1 \\
\hline جهت باد غالب & IT & مقدار شيب & V & فاصله از جادهها (m) & $r$ \\
\hline حداكثر سرعت باد (m/s) & r| & جهت شيب & $\wedge$ & فاصله از مناطق مسكونى (m) & r \\
\hline ميزان بارندكى (mm) & If & حداكثر دما (Co & 9 & جنس خاى & f \\
\hline & & حداقل دما ( & 1. & كاربرى زمين & $\Delta$ \\
\hline
\end{tabular}
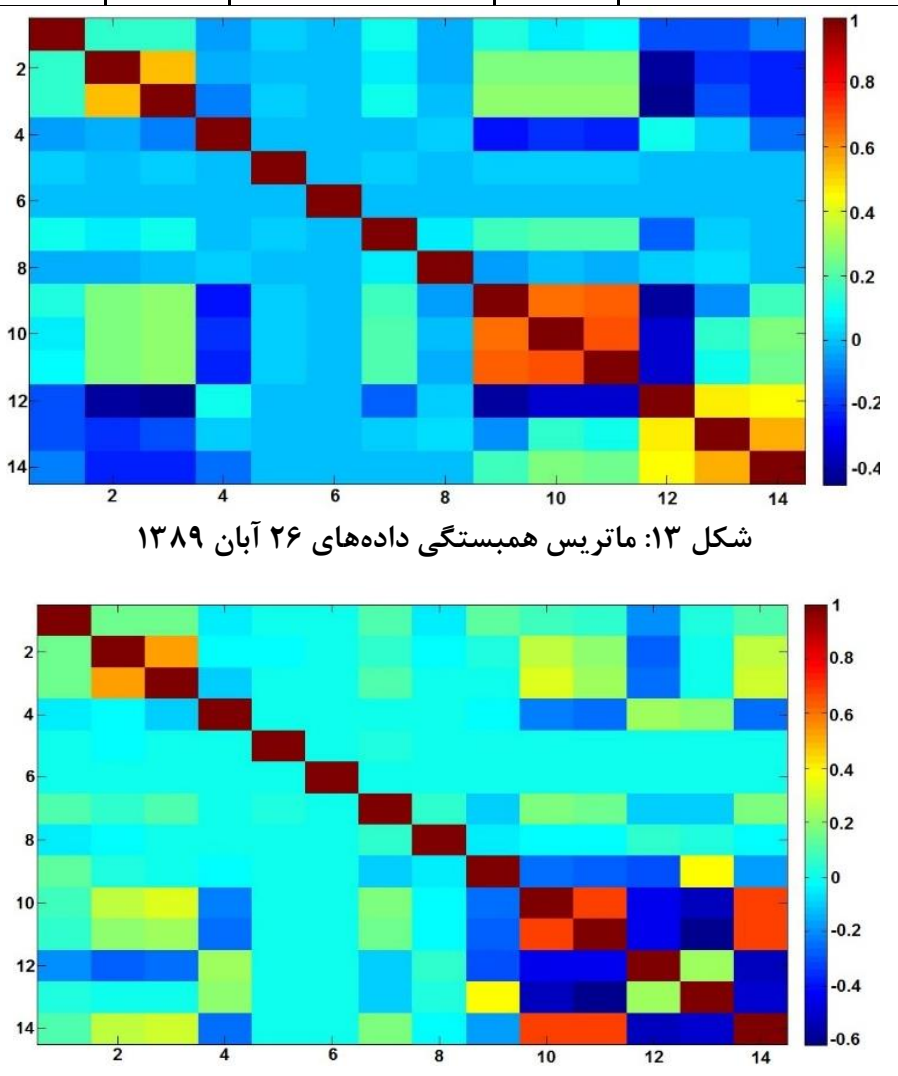

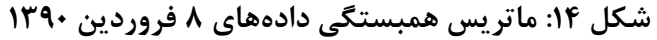

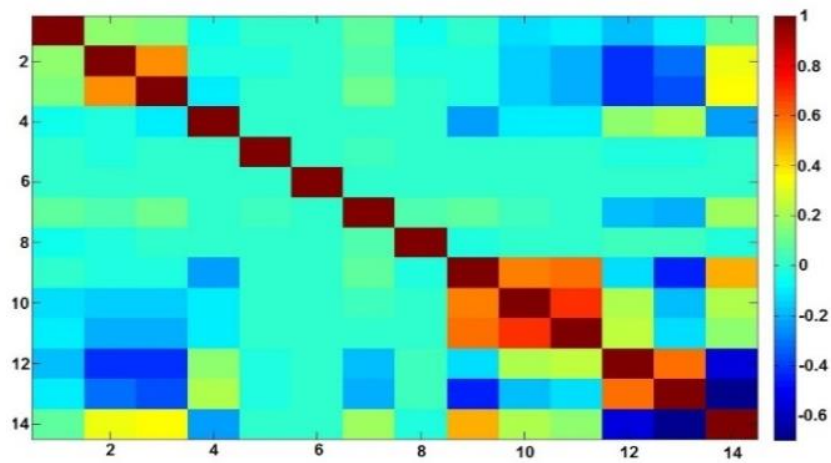

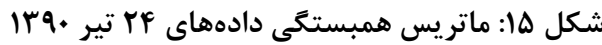


منـــاطق مســكونى، كـــاربرى زمـــين، مقــــار شــيب،

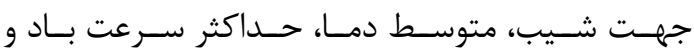

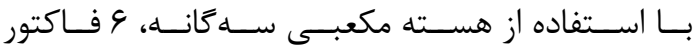
فاصله از جاده ها، جنس خاك، كـاربرى زمسين، ارتفـاع، هادئ

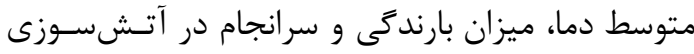

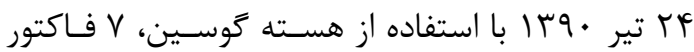
فاصـله از منــاطق مسـكونى، كـاربرى زمــين، ارتفــاع،

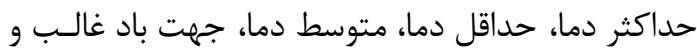
با استفاده از هسته مكعبى سهكانه، V فـاكتور فاصـله از جاز

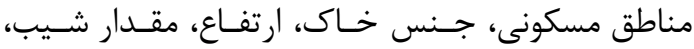
جهت شيب، حداقل دما و حداكثر سرعت باد به عنــوان فاكتورهاى موثر شناخته شدند. اين نتايج تا حد زيـادى

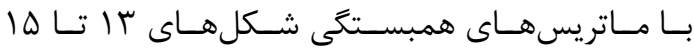

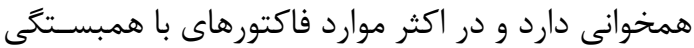

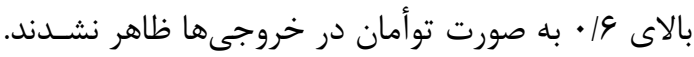

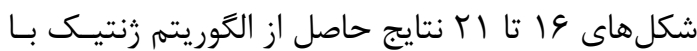
يارامترهاى مذكور در جدول r را نمايش مىدهند.

\begin{tabular}{|r|r|}
\hline Parameter & Value \\
\hline Population size & 10 \\
\hline Number of Generations & 100 \\
\hline Crossover rate & 0.8 \\
\hline Migration Fraction & 0.2 \\
\hline Migration Interval & 20 \\
\hline Scale (Gaussian Mutation) & 0.5 \\
\hline Shrink (Gaussian Mutation) & 0.7 \\
\hline Elite count & 1 \\
\hline
\end{tabular}

در الكوريتم GWR از هر دو هسـتهى روابـط (4) و (ه)

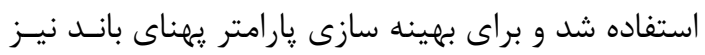

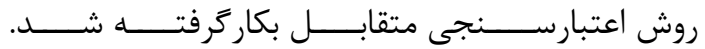

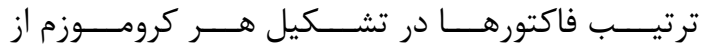

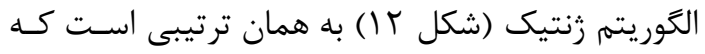
در جدول ا ارائه شده است. مقادير پارامترهاى الكَوريتم

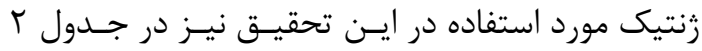

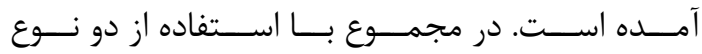

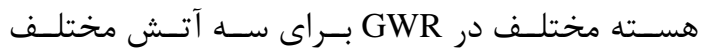
در منطقه مورد مطالعه، 9 حالت متفاوت خروجى داريم.

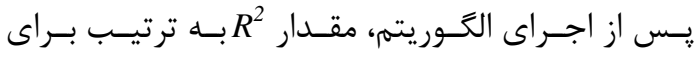

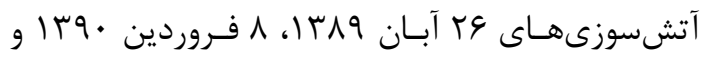

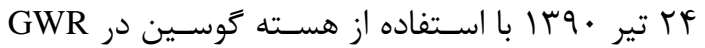

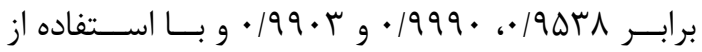

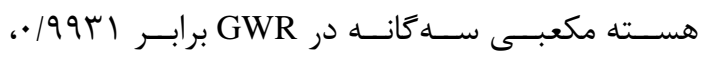

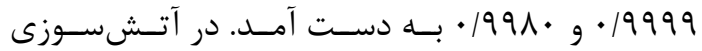

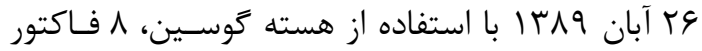

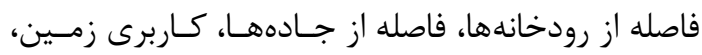

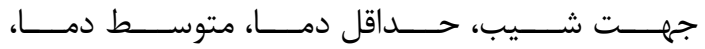

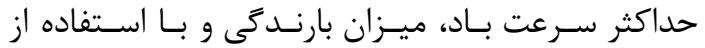

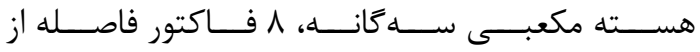

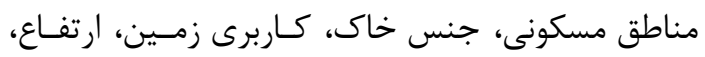

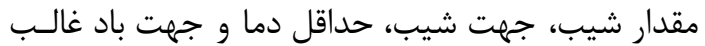

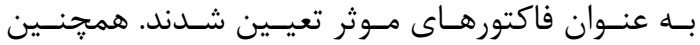

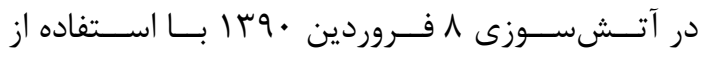

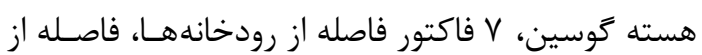



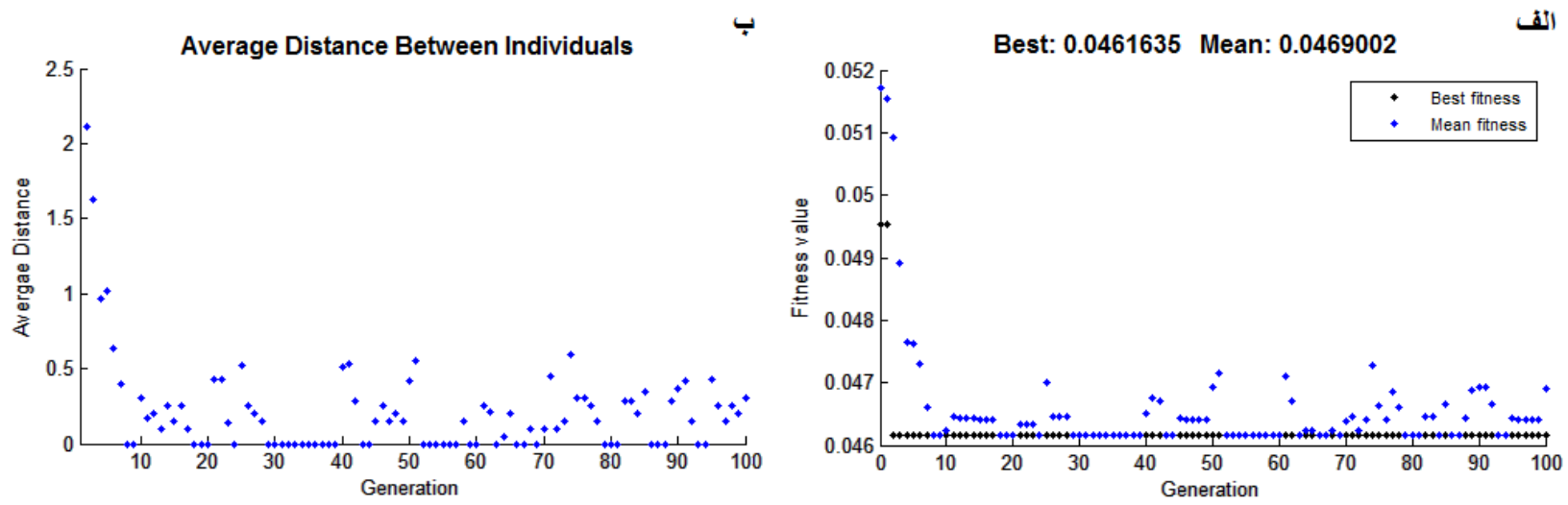

شكل عا: (الف) بهترين مقدار و ميانگين مقادير تابع برازش و (ب) ميانگين فاصله بين افراد هر نسل با استفاده از هسته گوسين

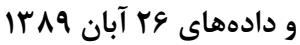
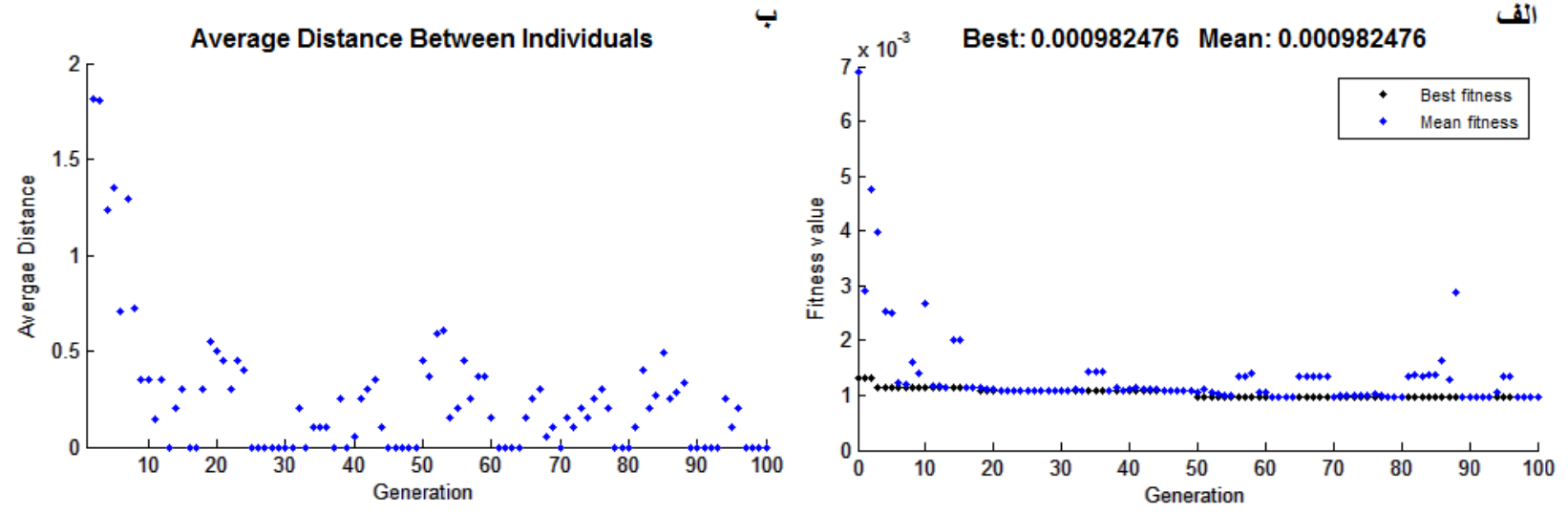

شكل Vا: (الف) بهترين مقدار و ميانگين مقادير تابع برازش و (ب) ميانگين فاصله بين افراد هر نسل با استفاده از هسته گوسين

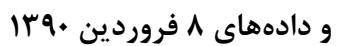
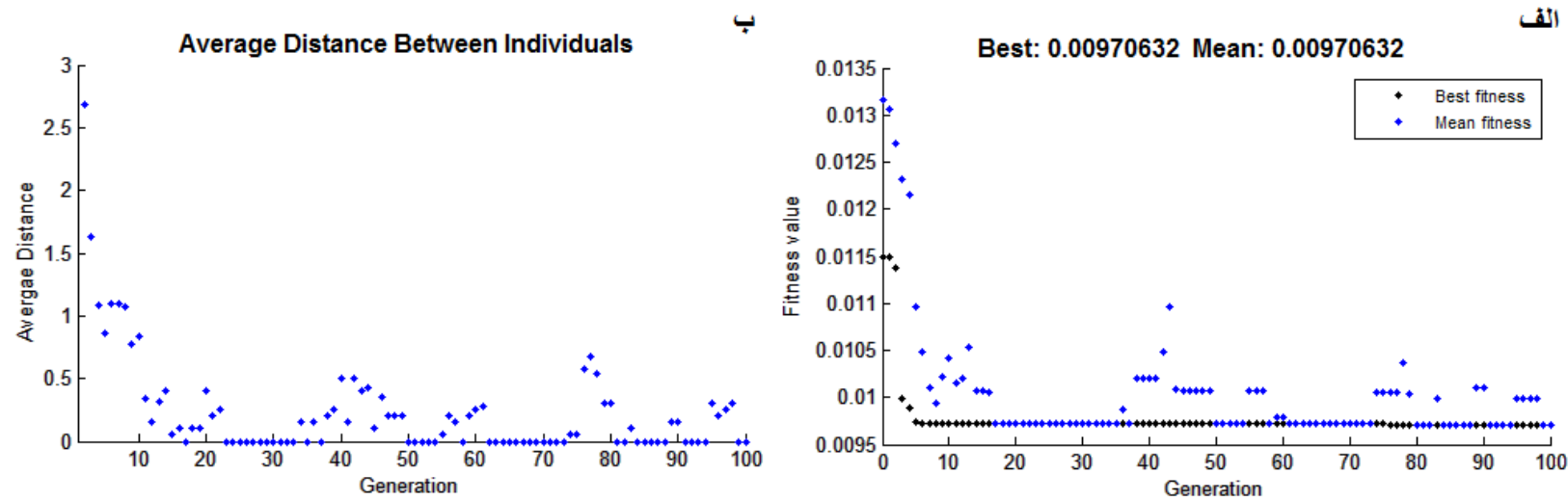

شكل ^ا: (الف) بهترين مقدار و ميانگين مقادير تابع برازش و (ب) ميانگين فاصله بين افراد هر نسل با استفاده از هسته گوسين

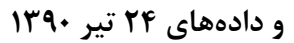



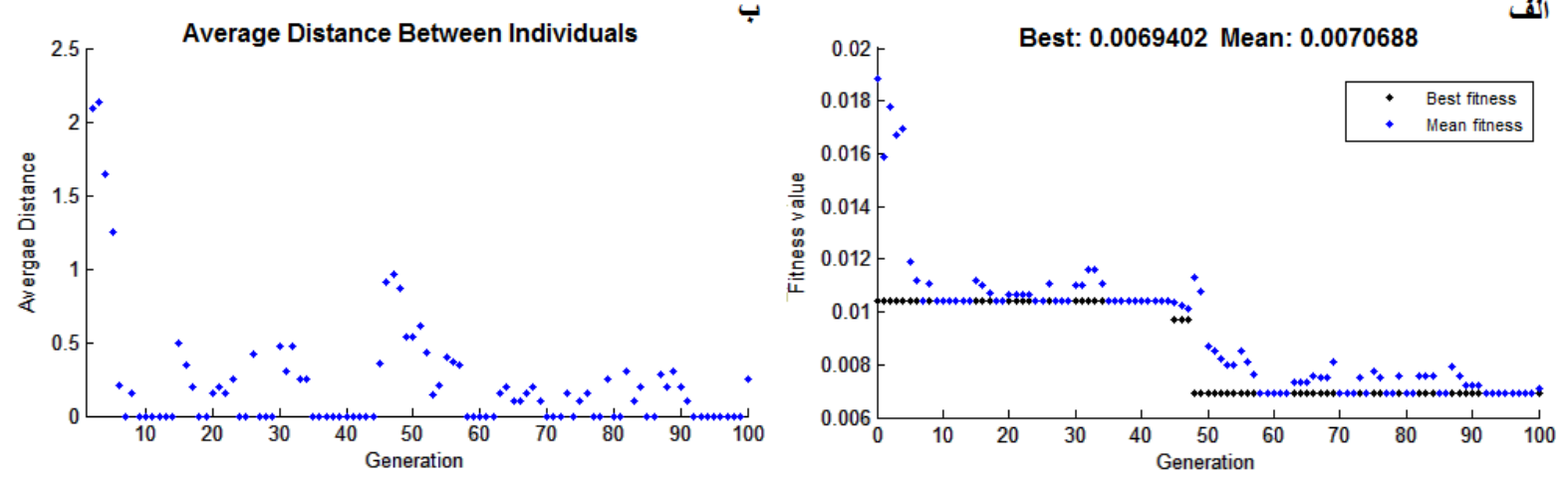

شكل 19: (الف) بهترين مقدار و ميانكين مقادير تابع برازش و (ب) ميانگين فاصله بين افراد هر نسل با استفاده از هسته مكعبى

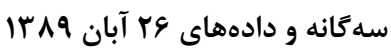
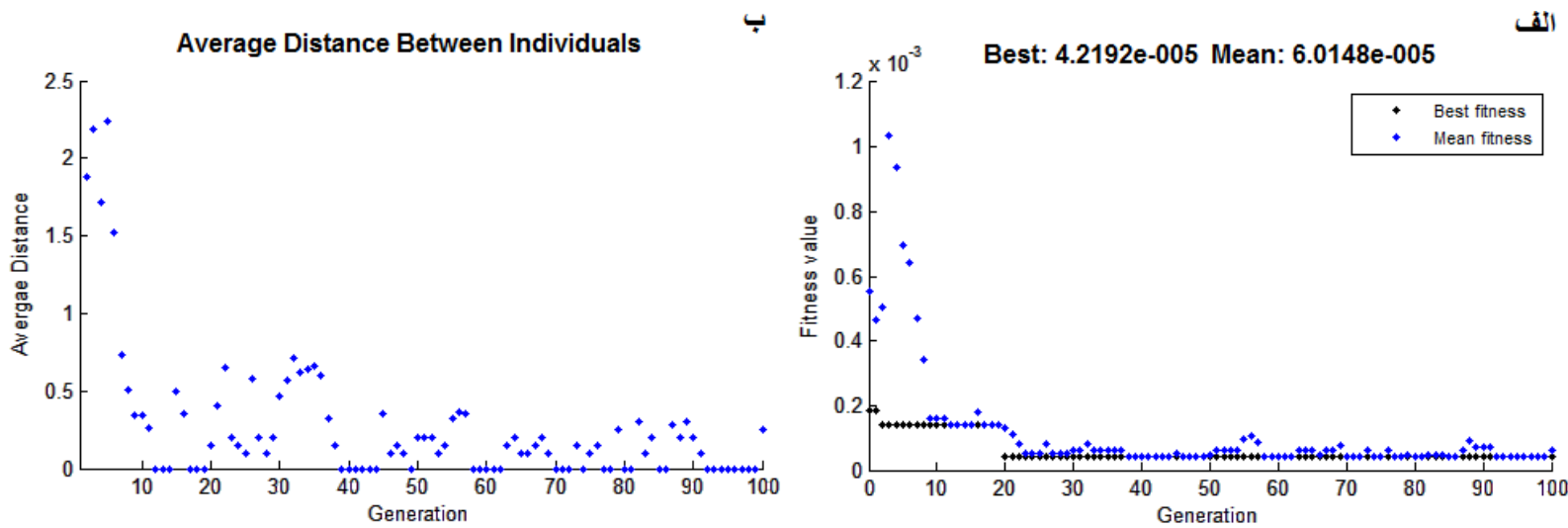

شكل •r: (الف) بهترين مقدار و ميانگين مقادير تابع برازش و (ب) ميانگين فاصله بين افراد هر نسل با استفاده از هسته مكعبى

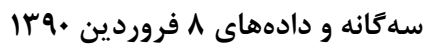
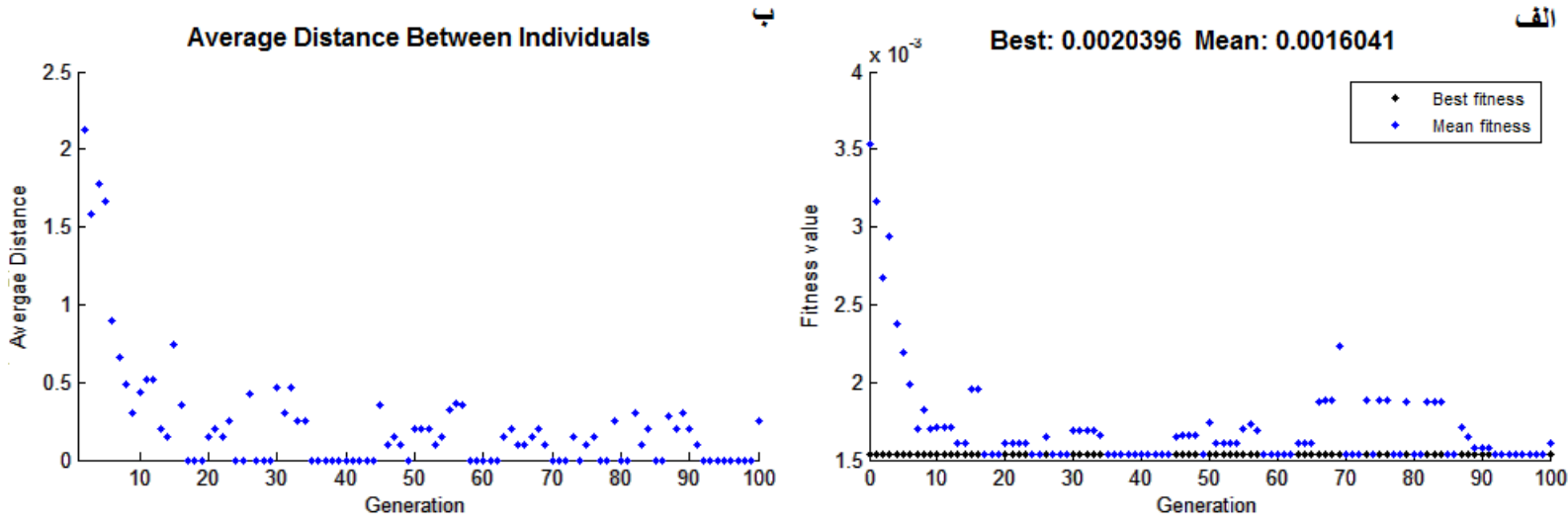

شكل آץ: (الف) بهترين مقدار و ميانگين مقادير تابع برازش و (ب) ميانگين فاصله بين افراد هر نسل با استفاده از هسته مكعبى

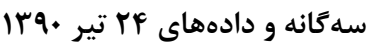

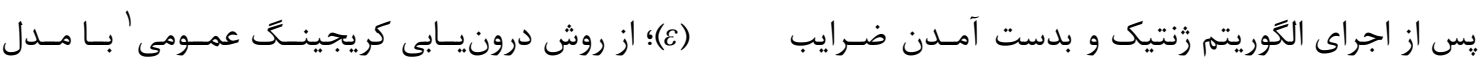

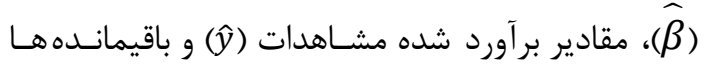

${ }^{1}$ Ordinary Kriging 


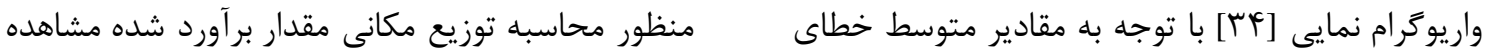

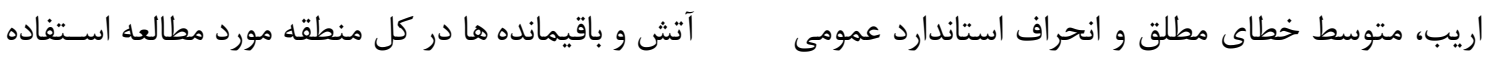

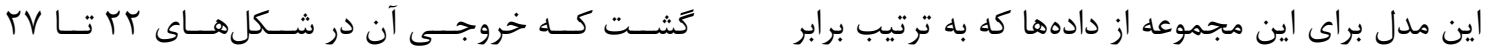

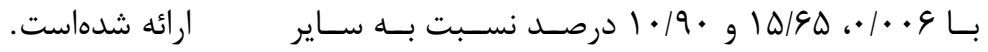

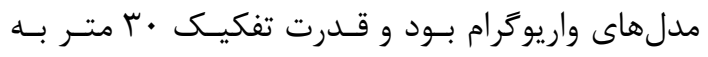

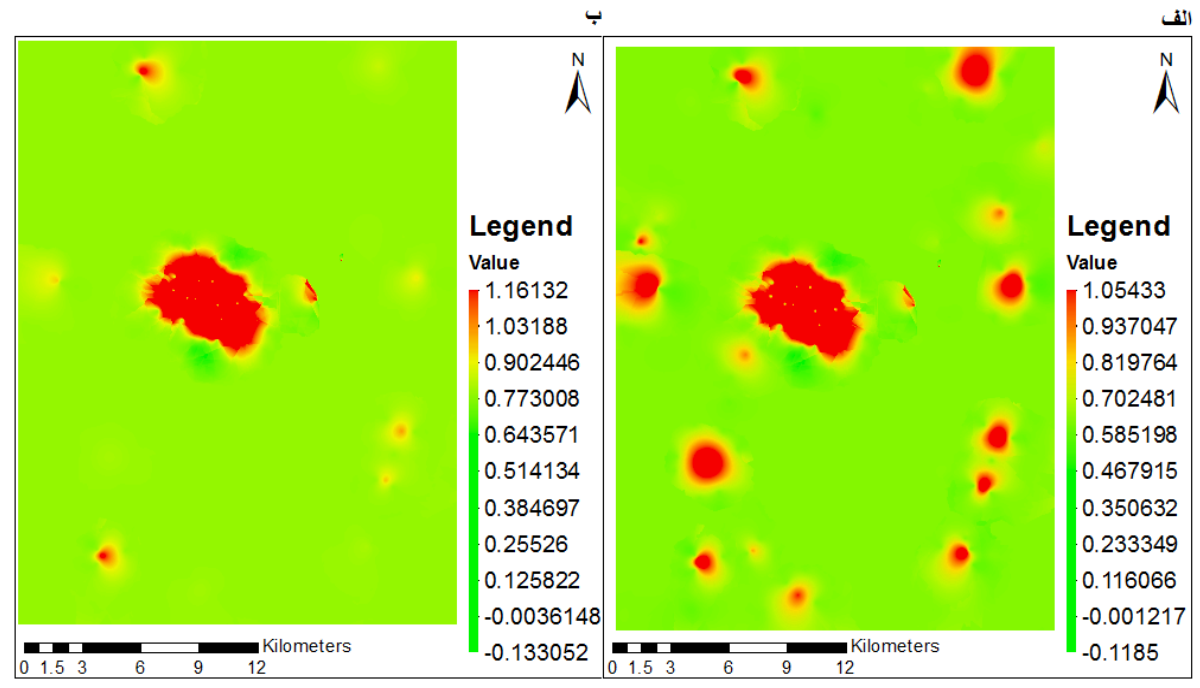

شكل זr: نمايش مقادير بر آورد شده مشاهدات وץ آبان 91/ا در منطقه مورد مطالعه با استفاده از هسته (الف) كوسين و (ب) مكعبى سهكانه

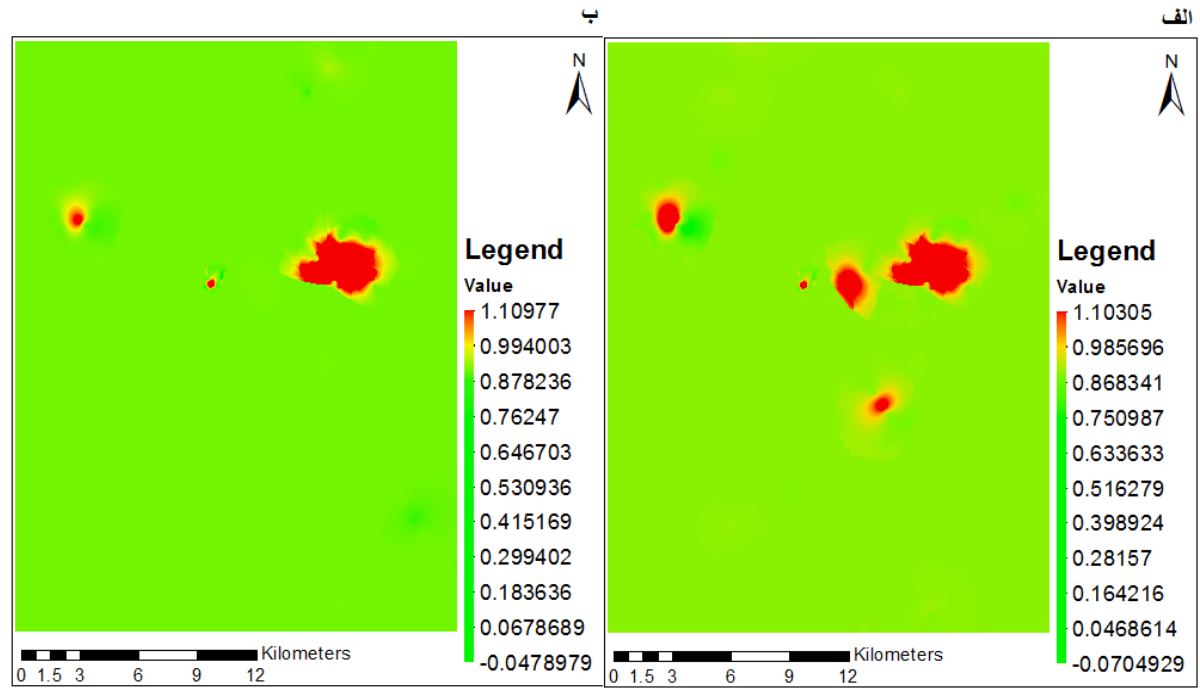

شكل سٓז: نمايش مقادير بر آورد شده مشاهدات 1 فروردين •qجادر منطقه مورد مطالعه با استفاده از هسته (الف) توسين و (ب) مكعبى سهكانه 


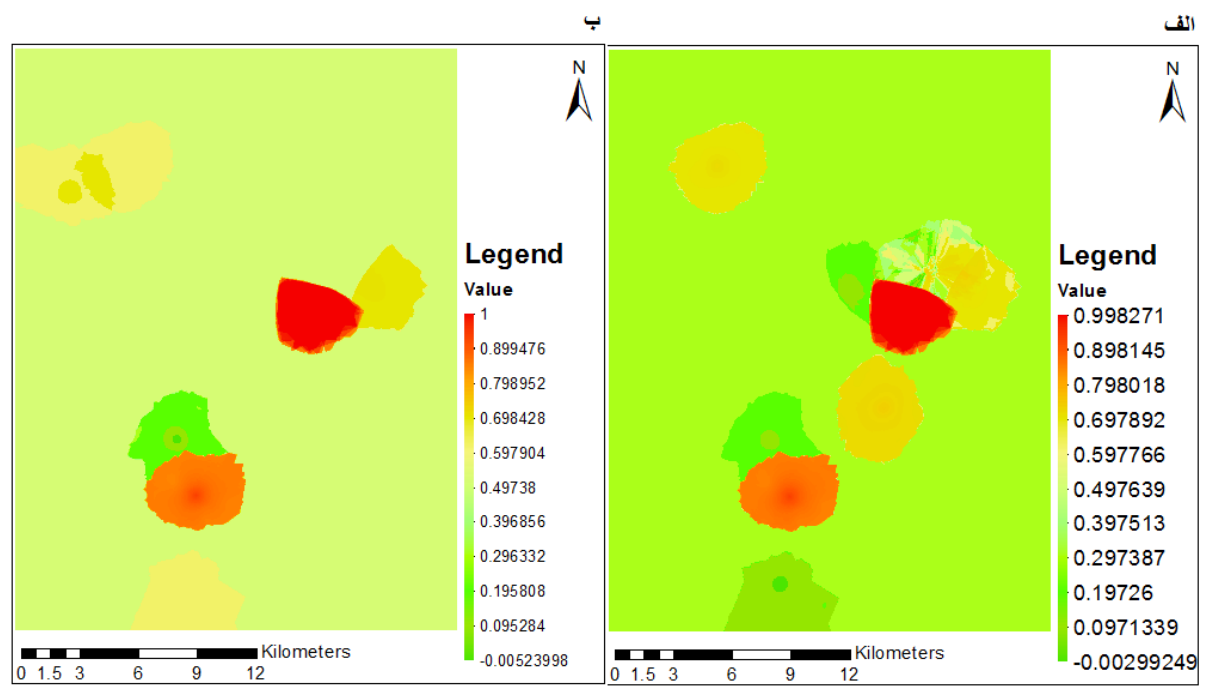

شكل FF: نمايش مقادير بر آورد شده مشاهدات TF تير •وسا در منطقه مورد مطالعه با استفاده از هسته (الف) كوسين و (ب) مكعبى سه كانه

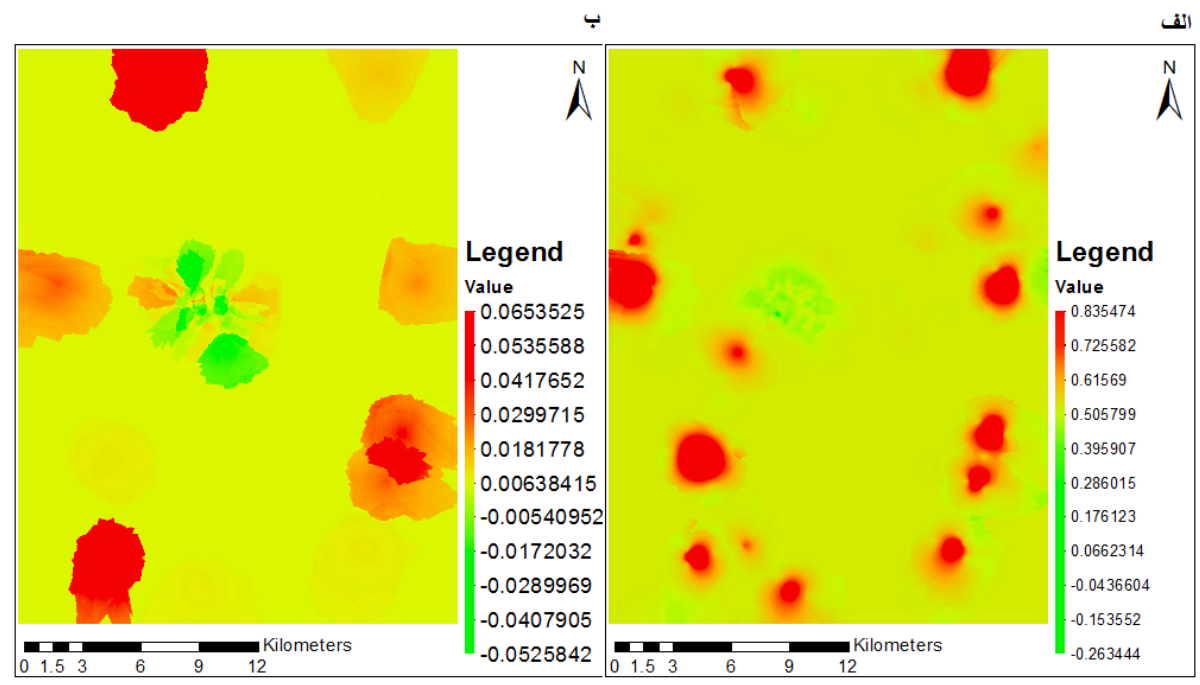

شكل هז: نمايش مقادير باقيمانده مدل در منطقه مورد مطالعه با استفاده از دادهاى \&ץ آبان

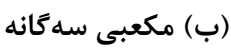




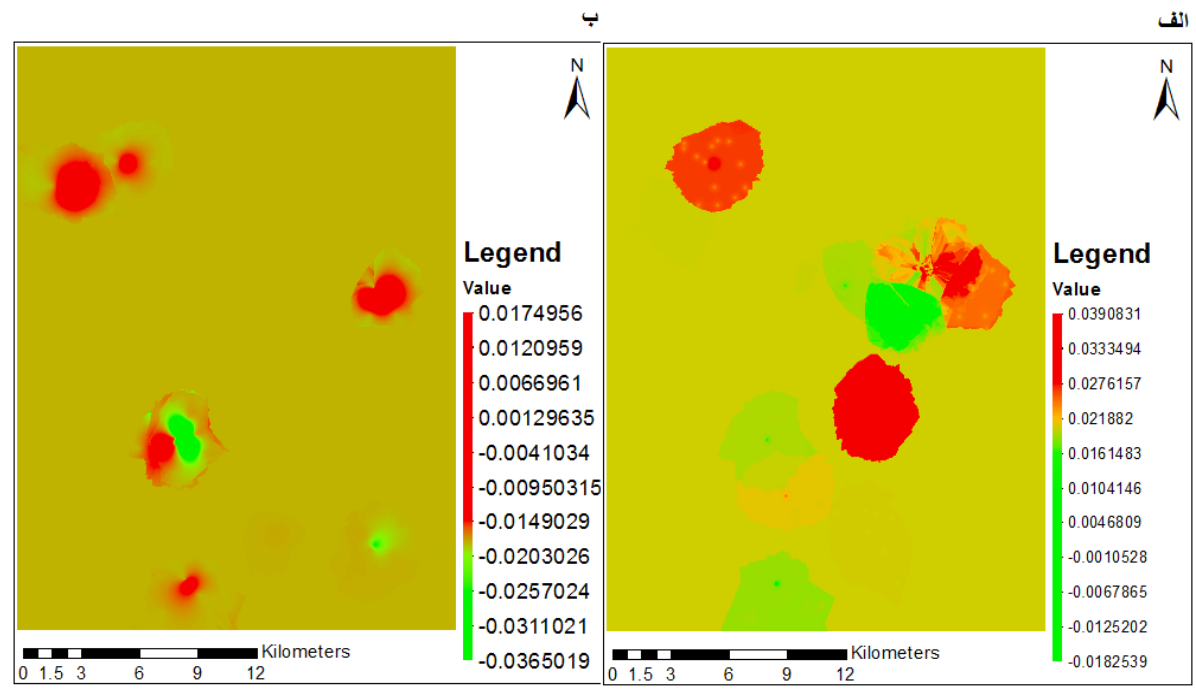

شكل צץ: نمايش مقادير باقيمانده مدل در منطقه مورد مطالعه با استفاده از دادههاى 1 فروردين •q با و هسته (الف) كوسين و (ب) مكعبى سه كانه

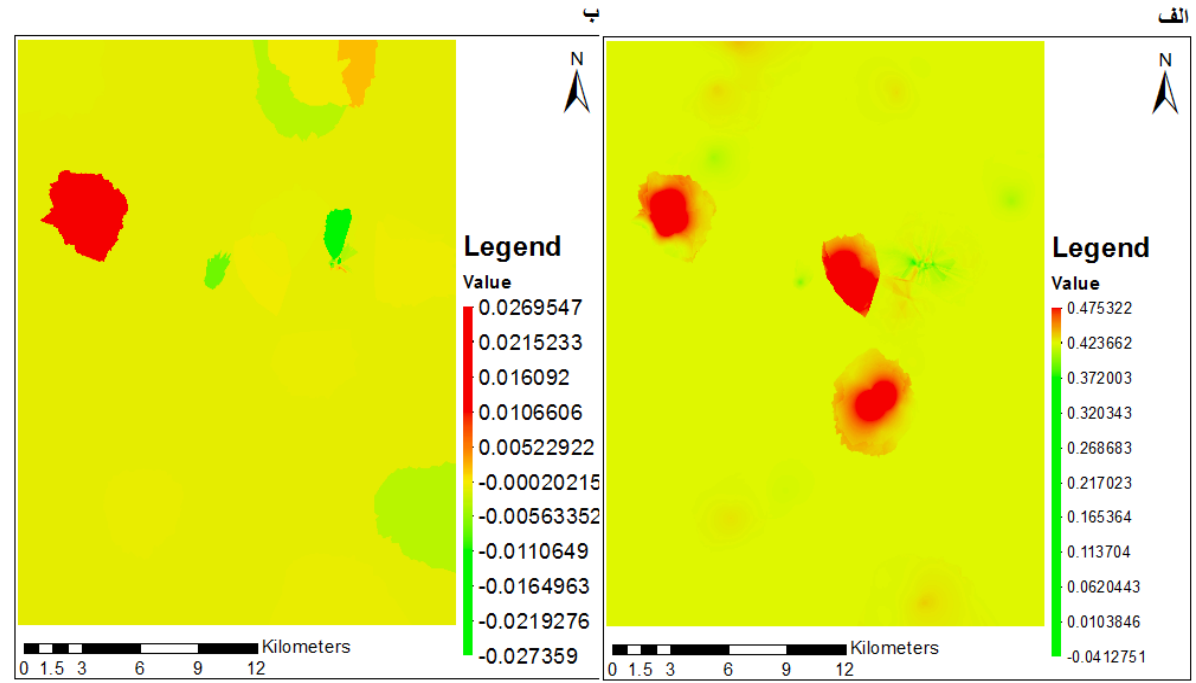

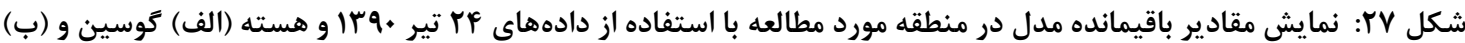
مكعبى سهكانه

تشخيص داده نشدند با علامت (-) مشخص شـدهانـد و

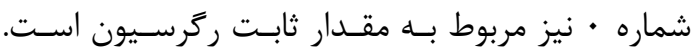

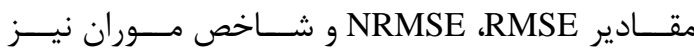

$$
\text { در جدول F آمده است. }
$$

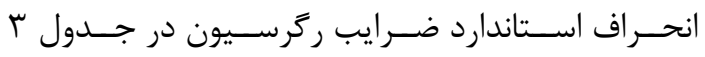

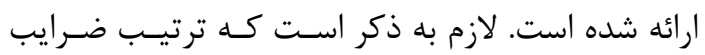

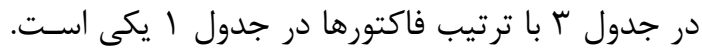

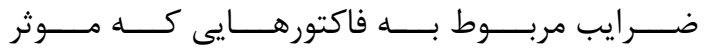


جدول بّ: انحراف استاندارد ضرايب ركرسيون حاصل از GWR در دو حالت استفاده از هسته (الف) توسين و (ب)

\begin{tabular}{|c|c|c|c|c|c|c|}
\hline \multicolumn{6}{|c|}{ مـعبى سه كاده } & \multirow[b]{3}{*}{ شماره } \\
\hline \multicolumn{3}{|c|}{ (ب) مكعبى سهَانه } & \multicolumn{3}{|c|}{ (الف) گَوسين } & \\
\hline F تير •q & ^ فروردين •وسا & צr آبان & Fr تير •وسا & ^ فروردين & צr آبان 9^זו & \\
\hline . /11D94G & 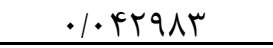 & $\Delta / \cdot \Delta \vee \wedge \Delta \Lambda$ & $.1 .911 \mathrm{~m} \Delta$ &.$/ 111 \mathrm{r} \Delta \Lambda$ & I/VTrt. & - \\
\hline- & - & - & - & $\left.\cdot|\cdots| \wedge\right|^{f}$ & $\cdot 1 \cdots \wedge \varepsilon$ & 1 \\
\hline- & $\cdot 1 \cdot \cdots \cdot \omega$ & - & - & - & $\cdot 1 \cdot \cdots 11 \mathrm{~F}^{\mathrm{f}}$ & $r$ \\
\hline $.1+11 \mathrm{~V}$ & - & $\cdot 1 \cdot \Delta \Delta \wedge Y$ & $\cdot 1 \cdot \cdots \Delta \Delta V$ & $\cdot 1 \cdots \mid 14 q$ & - & r \\
\hline$|Y / F \Delta V \wedge F|$ & r/Ar. sYq & 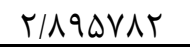 & - & - & - & f \\
\hline- & .1 .19991 & 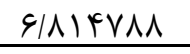 & $\cdot / \cdot r V \Delta \cdot r$ & .1 .91194 & $\cdot 1 \cdot \Delta 9191$ & $\Delta$ \\
\hline$\cdot 1 \cdot r \wedge \Delta T$ & $\cdot 1 \cdot \cdots \cdot \Delta \mathrm{V}$ & $\cdot 1 \cdot 11 \cdot \mathrm{FV}$ & $.1 \cdots 990$ & - & - & $\varepsilon$ \\
\hline $.1 \cdot$ trYSD & - & . $1 \cdot$ TFHFT & - & $\cdot 1 \cdot \cdot 1 \cdot 09$ & - & V \\
\hline$\cdot 1 \cdot \cdot r \Delta f^{c}$ & - & $\cdot 1 \cdot V r G \Delta$ & - & $\cdot|\cdots \Delta| \cdot$ & $\cdot 1 \cdots 199$ & $\Lambda$ \\
\hline- & - & - & 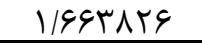 & - & - & 9 \\
\hline TI/AVFIFT & - & FN/q9яF. 1 & F/YFYGAV & - & TG/TAFVGI & $1 \cdot$ \\
\hline- & . $18 \wedge 9 \vee 1$. & - & $Y / V Y I \cdot V T$ & I/VG..VA & $\mid \Delta / 1 \cdot r q \Lambda$. & 11 \\
\hline- & - & INY.VYV & . $|\Delta T g T|$. & - & - & ir \\
\hline $1 \Delta / \Delta V q . q F$ & - & - & - & 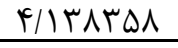 &.$/ V Y q 9 \Delta F$ & 11 \\
\hline- & $19 / \cdot 4194$. & - & - & - & IN/VTVI9Y & 14 \\
\hline
\end{tabular}

جدول F: مقدار NRMSE ،RMSE و شاخص موران باقيماندههاى مدل

\begin{tabular}{|c|c|c|c|c|c|c|}
\hline \multicolumn{3}{|c|}{ (ب) مكعبى سه گانه } & \multicolumn{3}{|c|}{ (الف) گَوسين } & \\
\hline F تير •وץ| & ^ فروردين & عץ آبان q^شו & F تير •وس| & ^ فروردين & צr آبان & \\
\hline $.1 \cdot 9.94$ & $\cdot 1 \cdot \cdots \vee \vee \wedge$ & . $\cdot r \cdot q r V$ & $\cdot / \cdot r q q \cdot \Lambda$ & . . . $\varphi \Delta s q$ & . . 9 & RMSE \\
\hline ./.tTVYI & . + rVD. & 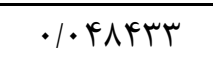 & $.1 .99 \& 4 V$ & •/. II Q9V & . & NRMSE \\
\hline . IGTKIFD & 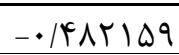 & -. |DTGFYI & ./V९人৭^। & . |qMVDKI &.$|9 q \mu \cdot r|$ & Moran's \\
\hline
\end{tabular}

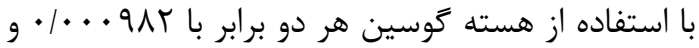

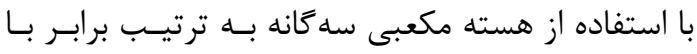

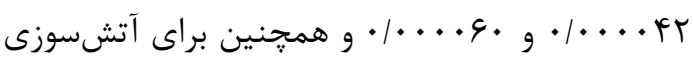

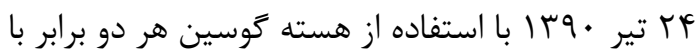

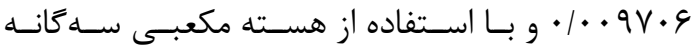

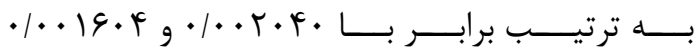

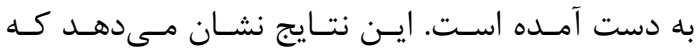

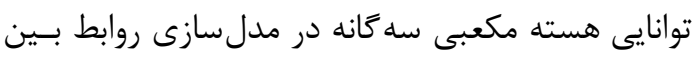

$$
\text { r-1- ارزيابى نتايج }
$$

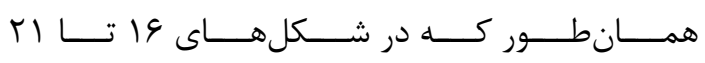
نشان داده شـده اسـت، بهتـــــن مقـدار تـابع بـرازش و

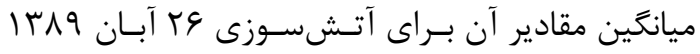

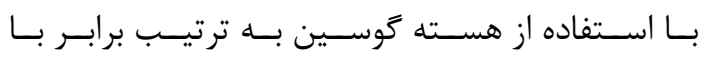

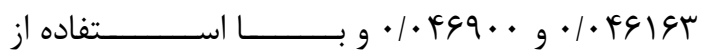

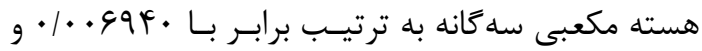

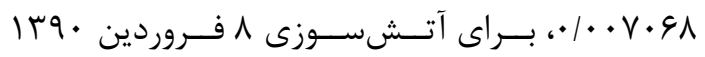




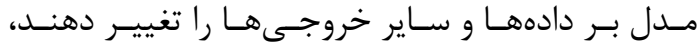

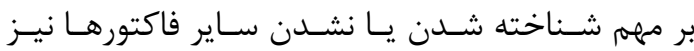

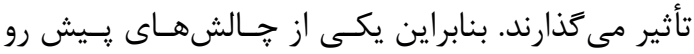
جمعآورى دادهاى كافى و مناسب است.

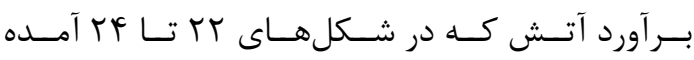

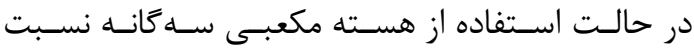

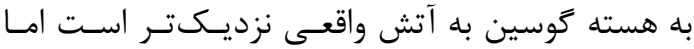

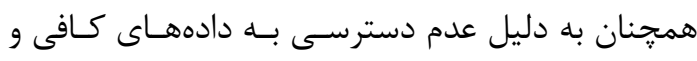

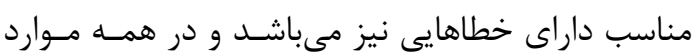
برآورد آتش نسبت به آتش واقعى مساحت بزرگتـرى راريا

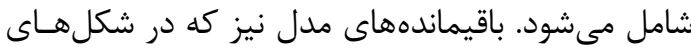
SD TV TV نشان داده شدهاند، در حالت استفاده از هسته

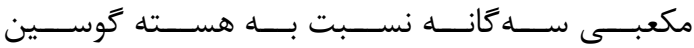

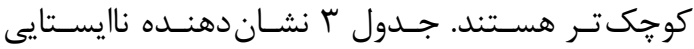

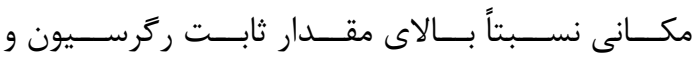

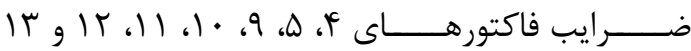

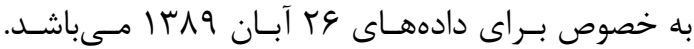
در ساير موارد ميزان اين نايستايى بسيار رِايين اسـت.

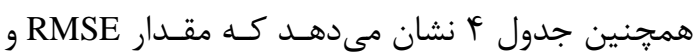
باقيماندههاى مدل در هر دو حالت استفاده از

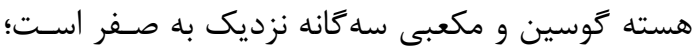

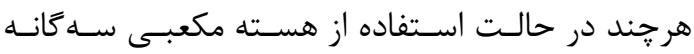
باقيماندها بسيار كوجىتر هستند.

همجنين در جدول f شاخص مـوران در هـر دو حالـت

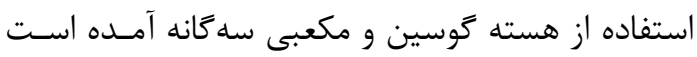

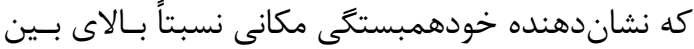

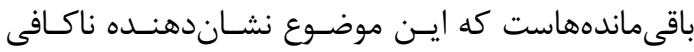

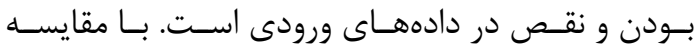

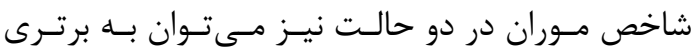

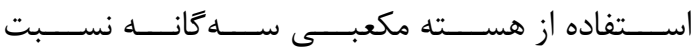

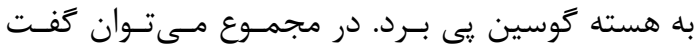

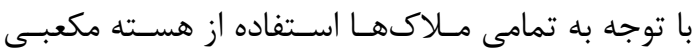
سه كَانه به نتايج بهترى انجاميد.
آتـشسـوزى و فاكتورهـاى موجـود در جـدول ا بـراى

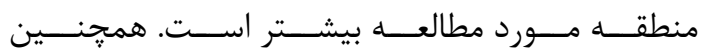
ميانكَين فاصله بين افراد هر نسل يا اصـطلاحاً تنـوع' را رمجان

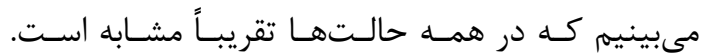

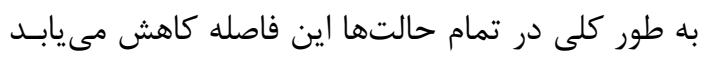

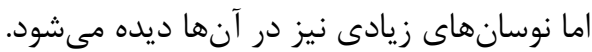

فاكتور كاربرى زمين در ه حالت، فاكتورهـاى فاصـله از

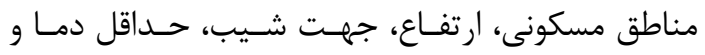

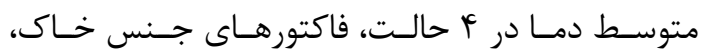

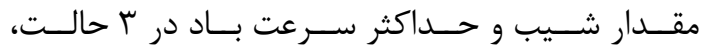
فاكتورهـاى فاصـله از رودخانـهـهـا، فاصـله از جـادهـــا،

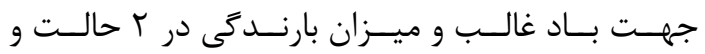
فاكتور حداكثر دما تنها در 1 حالت موثر شناخته شدند.

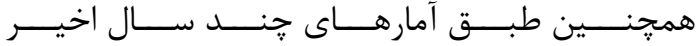

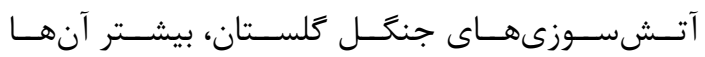

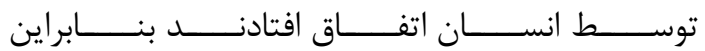

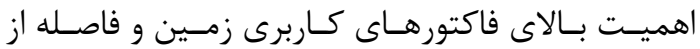

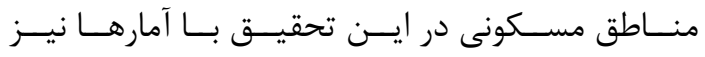

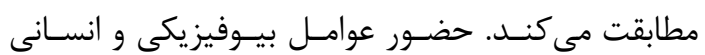

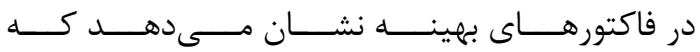

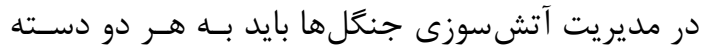

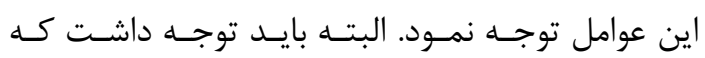
در اين تحقيق تنها ץ فاكتور انسانى وجود داشت كـه از ازئ

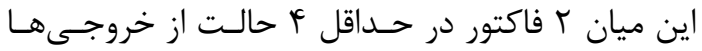
مههم تشخيص داده شدهاند كه اين با فرض اوليه تحقيق همخوانى دارد ولى براى دستيابى به نتـايج بهتــر بايسد

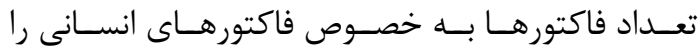

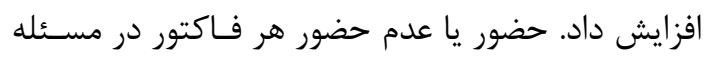

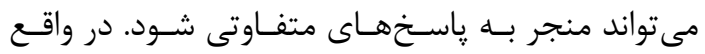
با افزودن فاكتورهاى جديد به مسئله، علاوه بر ايـن كـهـ

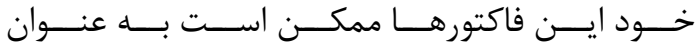

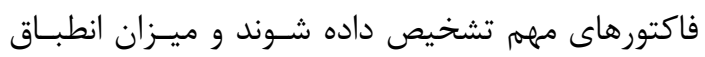

${ }^{22}$ diversity 
داشتند. از فاكتورهاى بيوفيزيكى ارتفاع، جهـت شـيب،

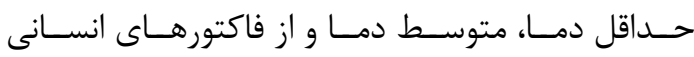

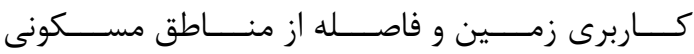

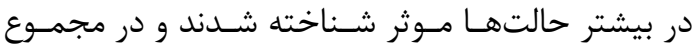

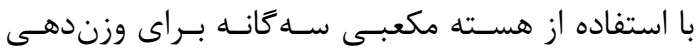
در GWR نتايج دقيقتر و مناسبترى به دست آمد. در تحقيقات آينده پِيشــهـاد مسىشـود تعـداد فاكتورهــا افزايش يابد. در اين زمينه مىتوان به فاكتورهاى انسانى

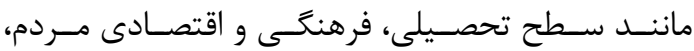

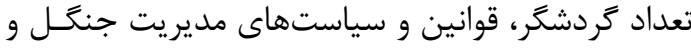

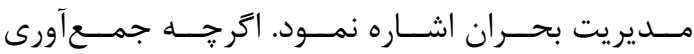

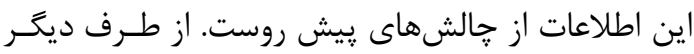
فاكتورهاى بيوفيزيكى ديكرى نيز مسىتـوان بـه مسـئله

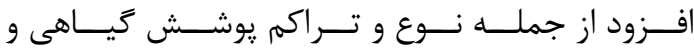

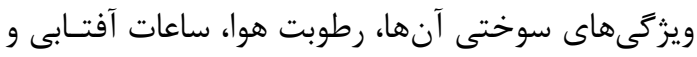

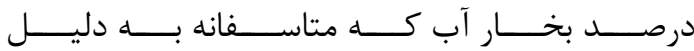

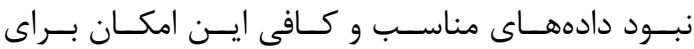

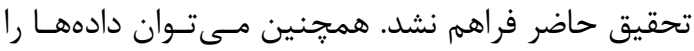

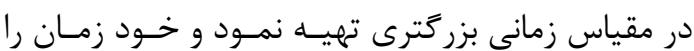

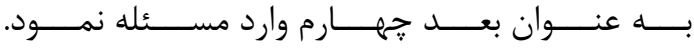

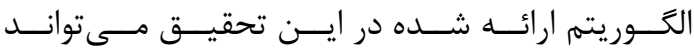
در كنار روشهاى ديكر مانند شناسايى آتش به وسـيله سنجش از دور براى دستيابى به نتايج بهتر به كار رود.

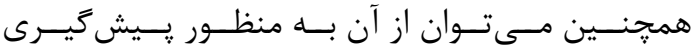
يا شناسايى به موقع آتش در پِيشبينى نحوه حركت آنس و كسترش آتش در جنغل بهره جست.

[1] Y. Bergeron, S. Gauthier, M. Flannigan, and V. Kafka, "Fire regimes at the transition between mixed wood and coniferous boreal forest in Northwestern Quebec", Ecology, Vol.85, No.7, PP. 1916-1932, 2004.

[2] P. F. Hessburg, J. K. Agee, and J. F. Franklin, "Dry forests and wildland fires of the inland Northwest USA: Contrasting the landscape ecology of the pre-settlement and

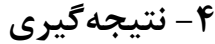

امروزه شناسايى عوامل موثر بر آتشسوزى جنَــلهـــاز از

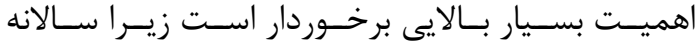

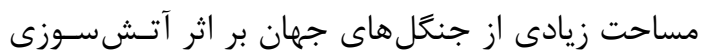

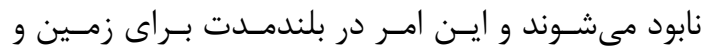

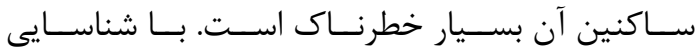

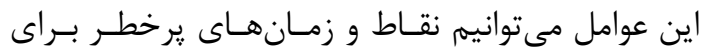

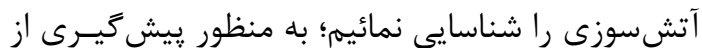

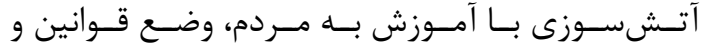

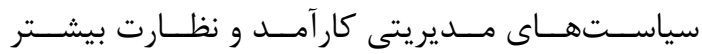

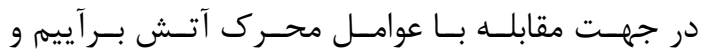

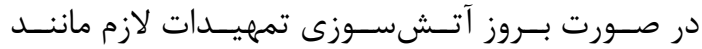
استقرار وسايل اطفاء حريق در نزديكى نقاط خطرناك و ايجاد راههاى دسترسى آسان به اين نقاط را بينديشيم.

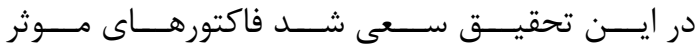
بر آتشسوزىهاى جنكل كلستان را شناسايى نمـائيم و

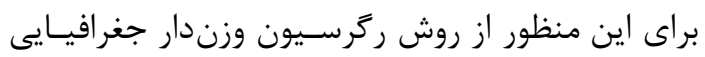

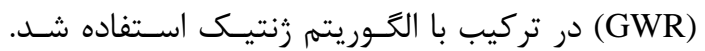

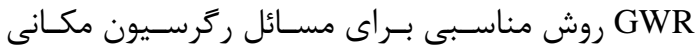

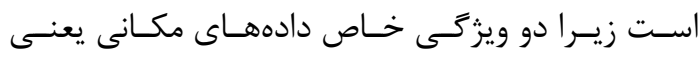
خودهمبسـتخى و نايستـايى مكـانى را در حـل مسئله

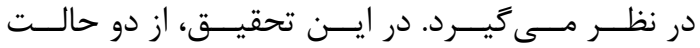

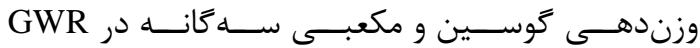

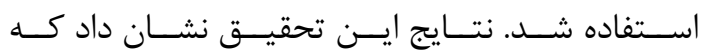

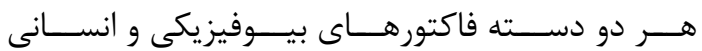
تأثير بسزايى در آتشسوزىهاى منطقـهـ مـورد مطالعـهـ

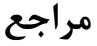

modem eras", For. Ecol. Manage. Vol.211, No.1-2, PP. 117-139, 2005.

[3] J. Martinez-Fernandez, E. Chuvieco and N. Koutsias, "Modeling long-term fire occurrence factors in Spain by accounting for local variations with geographically weighted regression", Natural Hazards and Earth System Sciences, Vol.13, PP. 311327, 2013. 
[4] B. G. Dickson, J. W. Prather, Y. Xu, H. M. Hampton, E. N. Aumack and T. D. Sisk, "Mapping the probability of large fire occurrence in northern Arizona, USA", Landscape Ecology, Vol.21, PP. 747-761, 2006.

[5] D. C. Odion, E. J. Frost, J. R. Strittholt, H. Jiang, D. A. Della-Salla and M. A. Moritz, "Patterns of fire severity and forest conditions in the western Klamath Mountains, north-western California" Conservation Biology, Vol.18, PP. 927-936, 2004.

[6] J. P. Prestemon, J. M. Pye, D. T. Butry, T. P. Holmes and D. E. Mercer, "Understanding broad scale wildfire risks in a humandominated landscape", For. Sci. Vol.48, PP. 685-693, 2002.

[7] D. E. Mercer and J. P. Prestemon, "Comparing production function models for wildfire risk analysis in the wildland-urban interface", For. Policy Economics, Vol.7, No.5, PP. 782-795, 2005.

[8] M. A. Moritz, J. E. Keeley, E. A. Johnson and A. A. Schaffner, "Testing a basic assumption of shrubland fire management: How important is fuel age?", Frontiers Ecol. Environm. Vol.2, PP. 67-72, 2004.

[9] J. Yang, H. S. He, S. R. Shifley and E. J. Gustafson, "Spatial Patterns of Modern Period Human-Caused Fire Occurrence in the Missouri Ozark Highlands", Forest Science, Vol.53, No.1, PP. 1-15, 2007.

[10] C. M. Countryman, "The fire environment concept", USDA Forest Service, Pacific Southwest Forest and Range Experiment Station, General Technical Report PSW-7. Berkeley, CA, 1972.

[11]R. A. Bradstock, A. M. Gill, B. J. Kenny and J. Scott, "Bushfire risk at the urban interface estimated from his-torical weather records: consequences for the use of prescribed fire in the Sydney region of south-eastern Australia", Journal of Environmental Management, Vol.52, PP. 259-271, 1998.
[12] J. S. Fried, G. Winter and J. K. Gilless, "Assessing the benefits of reducing fire risk in the wildland-urban in-terface: a contingent valuation approach", International Journal of Wildland Fire, Vol.9, PP. 9-20, 1999.

[13]C. Diaz-Avalos, D. L. Peterson, E. Alvarado, S. A. Ferguson and J. E. Besag, "Space-time modeling of lightning-caused ignitions in the Blue Mountains, Oregon", Canadian Journal of Forest Research, Vol.31, PP. 1579-1593, 2001.

[14]R. E. Burgan and R. C. Rothermel, "BEHAVE: fire prediction and fuel modeling system-fuel subsystem", USDA Forest Service, Intermountain Research Station, General Technical Report INT-167. Ogden, UT, 1984.

[15]Forestry Canada Fire Danger Group Development and structure of the Canadian Forest Fire Behaviour Predic-tion System, Forestry Canada, Science and Sustainable Development Directorate Report ST-X-3. Ottawa, ON, 1992.

[16] M. Larjavaara, J. Pennanen and T. J. Tuomi, "Lightning that ignites forest fires in Finland", Agricultural and Forest Meteorology, Vol.132, PP. 171-180, 2005.

[17]B. M. Wotton and D. L. Martell, "A lightning fire occurrence model for Ontario", Canadian Journal of Forest Research, Vol.35, PP. 1389-1401, 2005.

[18] K. L. Pew and C. P. S. Larsen, "GIS analysis of spatial and temporal patterns of humancaused wildfires in the temperate rainforest of Vancouver Island, Canada", Forest Ecology and Management, Vol.140, PP. 118, 2001.

[19] Y. H. Chou, "Spatial autocorrelation and weighting functions in the distribution of wildland fires", International Journal of Wildland Fire, Vol.2, PP. 169-176, 1992.

[20] Y. H. Chou, R. A. Minnich and R. A. Chase, "Mapping probability of fire occurrence in San Jacinto Mountains, California, USA", Environmental Management, Vol.17, PP. 
129-140, 1993.

[21] A. D. Syphard, V. C. Radeloff, J. E. Keeley, T. J. Hawbaker, M. K. Clayton, S. I. Stewart and R. B. Hammer, "Human influence on California fire regimes", Ecological Applications, Vol.17, PP. 1388-1402, 2007.

[22] T. D. A. Rodriguez, M. H. Ramirez and J. H. Tchikoue, "Factors affecting the accident rate of forest fires", Ciencia Forestal en Mexico, Vol.33, No.104, PP. 38-57, 2008.

[23]C. R. Roman and V. M. J. Martinez, "Effectiveness of protected areas in mitigating fire within their boundaries: Case study of Chiapas, Mexico", Conservation Biology, Vol.20, No.4, PP. 1074-1086, 2006.

[24] A. D. Syphard, V. C. Radeloff, N. S. Keuler, R. S. Taylor, T. J. Hawbaker, S. I. Stewart and M. K. Clayton, "Predicting spatial patterns of fire on a southern California landscape", International Journal of Wildland Fire, Vol.17, PP. 602-613, 2008.

[25] R Romero-Calcerrada, C. J. Novillo, J. D. A. Millington and I. Gomez-Jimenez, "GIS analysis of spatial patterns of human-caused wildfire ignition risk in the SW of Madrid (Central Spain)", Landscape Ecol. Vol.23, PP. 341-354, 2008.

[26]E. Erten, V. Kurgun, and N. Musaolu, "Forest fire risk zone mapping from satellite imagery and risk: A recent case study from Mt. Carmel (Israel)", Forest Ecology and Management, Vol.262, PP. 1184-1188, 2005.

[27]F. D. Y. Avila, G. M. Pompa and P. E. Vargas, "Spatial analysis of fire occurrence in the Durango state. Revista Chapingo", Serie Ciencias Forestales, Vol.16, No.2, 2010.

[28]C. Brunsdon, S. Fotheringham and M. Charlton, "Geographically weighted regression - modelling spatial nonstationarity", The Statistician, Vol.47, No.3, PP. 431-443, 1998.

[29] F. D. Y. Avila, M. Pompa-Garcia, X.
Antonio-Nemiga, D.A. Rodriguez-Trejo, E. Vargas-Perez and J. Santillan-Perez, "Driving Factors for Forest Fire Occurrence in Durango State of Mexico: A Geospatial Perspective", Chin. Geogra. Sci. Vol.20, No.6, PP. 491-497, 2010.

[30]A. C. L. Sa, J. M. C. Pereira, M. E. Charlton, B. Mota, P. M. Barbosa and A. S. Fotheringham, "The pyrogeog-raphy of subSaharan Africa: a study of the spatial nonstationarity of fire-environment relationships using GWR", J. Geogr. Syst. Vol.13, PP. 227-248, 2011.

[31] W. R. Tobler, "A computer movie simulating urban growth in the Detroit region", Economic Geography, Vol.46, No.2, PP. 234-24, 1970.

[32]D. P. McMillen and J. F. McDonald, "Locally weighted maximum likelihood estimation: Monte Carlo evidence and an application", presented at the Regional Science Association International meetings, Santa Fe, NM, 1998.

[33]M. Charlton and A. S. Fotheringham, "Geographically Weighted Regression", White Paper. Kildare, Ireland: National Centre for Geocomputation, National University of Ireland, Maynooth, 17, 2009.

[34] S. Shekhar, and H. Xiong. "Encyclopedia of GIS”, Springer Science \& Business Media, 2008.

[35]A. Cliff and K. Ord, "Testing for spatial autocorrelation among regression residuals", Geographical Analysis Vol.4, No.3, PP. 267284,1972 .

[36] M. Hasanlou and F. Samadzadegan, "ICA/PCA base genetically band selection for classification of Hyperspectral images", presented at the 31st Asian Conference on Remote Sensing, announcer, 2010.

[37] P. Dale. "Mathematical Techniques in GIS, Second Edition”, CRC Press, 2014. 


\title{
Determining Effective Factors on Forest Fire Using the Compound of Geographically Weighted Regression and Genetic Algorithm, a Case Study: Golestan, Iran
}

Amin Raei ${ }^{1}$, Parham Pahlavani ${ }^{* 2}$, Mahdi Hasanlou ${ }^{2}$

1-Ms.c student of GIS in Department of Surveying and Geomatics Engineering, College of Engineering, University of Tehran 2- Assistant professor in Department of Surveying and Geomatics Engineering, College of Engineering, University of Tehran

\begin{abstract}
Determining the effective factors on fire is so important, because the plenty areas of forests around the world are destroyed every year by fire. It helps us to identify most dangerous locations and times in forest fire. Hence, we can prevent many of driving factors of forest fire by law enforcement, efficient forest management policies and more supervision. In the current study, we identified the impressive factors on the fire in Golestan forest using the compound of Geographically Weighted Regression (GWR) method and Genetic Algorithm that is suitable for the spatial regression problem, because it obtains the effective factors considering the autocorrelation and non-stationarity properties of spatial data. In this study, three different fire areas as well as two kernels of Gaussian and Tricube for weighting of GWR were used that for these three fire areas resulted to $\mathrm{R}^{2}=0.9538, \mathrm{R}^{2}=0.9990$, and $\mathrm{R}^{2}=0.9903$ for Gaussian kernel and $\mathrm{R}^{2}=0.9931, \mathrm{R}^{2}=0.9999$, and $\mathrm{R}^{2}=0.9980$ for Tricube kernel, respectively. This research shows that both of the biophysical and anthropogenic factors have significant effects on forest fire in our study areas. In biophysical factors, the elevation, the aspect, the minimum and mean tempreture and in anthropogenic factors, the landuse and the distance from the residential areas were identified as the most impressive factors. Weighting by Tricube kernel concluded to more precise results.
\end{abstract}

Key words: Forest Fire, Geographically Weighted Regression, Genetic Algorithm, Golestan Forest

Correspondence Address: Department of Surveying and Geomatics Engineering, College of Engineering, University of Tehran, Tehran, Iran. Tel: 021-61114524.

Email: pahlavani @ut.ac.ir 